\title{
COVID-19 and urban rivers: Effects of lockdown period on surface water pollution and quality- A case study of the Zarjoub River, north of Iran
}

\author{
Hamed Haghnazar ${ }^{1}$ Jeffrey A Cunningham ${ }^{2} \cdot$ Vinod Kumar $^{3} \cdot$ Ehsan Aghayani ${ }^{4} \cdot$ Mojtaba Mehraein $^{5}$
}

Received: 16 September 2021 / Accepted: 19 December 2021 / Published online: 3 January 2022

(c) The Author(s), under exclusive licence to Springer-Verlag GmbH Germany, part of Springer Nature 2022

\begin{abstract}
Due to the spreading of the coronavirus (COVID-19) in Iran, restrictions and lockdown were announced to control the infection. In order to determine the effects of the lockdown period on the status of the water quality and pollution, the concentrations of $\mathrm{Al}, \mathrm{As}, \mathrm{Ba}, \mathrm{Cr}, \mathrm{Cu}, \mathrm{Mo}, \mathrm{Ni}, \mathrm{Pb}, \mathrm{Se}$, and $\mathrm{Zn}$, together with $\mathrm{Na}^{+}, \mathrm{Mg}^{2+}, \mathrm{Ca}^{2+}$ and electrical conductivity (EC), were measured in the Zarjoub River, north of Iran, in both pre-lockdown and post-lockdown periods. The results indicated that water pollution and associated human health risk reduced by an average of 30\% and 39\%, respectively, during the lockdown period. In addition, the multi-purpose water quality index also improved by an average of $34 \%$. However, the water salinity and alkalinity increased during the lockdown period due to the increase of municipal wastewater and the use of disinfectants. The major sources of pollution were identified as weathering, municipal wastewater, industrial and agricultural effluents, solid waste, and vehicular pollution. PCA-MLR receptor model showed that the contribution of mixed sources of weathering and municipal wastewater in water pollution increased from 23 to $50 \%$ during the lockdown period. However, the contribution of mixed sources of industrial effluents and solid wastes reduced from 64 to $45 \%$. Likewise, the contribution of traffic-related sources exhibited a reduction from $13 \%$ in the pre-lockdown period to $5 \%$ together with agricultural effluent in the post-lockdown period. Overall, although the lockdown period resulted in positive impacts on diminishing the level of water pollution caused by industrial and vehicular contaminants, the increase of municipal waste and wastewater is a negative consequence of the lockdown period.
\end{abstract}

Keywords COVID-19 $\cdot$ Lockdown $\cdot$ Water pollution $\cdot$ PCA-MLR $\cdot$ Hazardous elements

\section{Introduction}

The novel coronavirus (COVID-19) began to spread throughout the world towards the end of 2019 (Mandal and Pal, 2020; Zhang et al. 2021). With infection across 210 countries and the rising number of death, World Health Organization (WHO) declared the COVID-19 outbreak as a global pandemic and health emergency (Mahmood et al. 2020). The WHO persuaded countries to build around a comprehensive strategy to prevent infections, save lives, and minimize impact (WHO 2020a). On February 19, 2020, the first confirmed cases in Iran were identified in Qom province and quickly extended across the whole country (Raoofi et al. 2020). Due to the remarkable increase in the number of confirmed cases, the government induced people to stay at home by applying restrictions to avoid the transmission of viruses. The WHO was grateful for the measures being taken in Iran to control their epidemics (WHO. 2020b). The 
initial closures started at the end of February 2020 by shutting down the schools, universities, risky businesses, and all cultural and religious events in Iran (Daneshpazhooh and Mahmoudi, 2021). With the beginning of the Nowruz holidays on March, 21 2020, the severe lockdown was in place simultaneously except for only essential businesses and continued until April, 182020 (Hoseini and Valizadeh, 2021).

Many studies reported that significant changes in the environment were observed throughout the world during the lockdown period. For instance, an improvement in the levels of air quality and greenhouse gasses (Wang and Su, 2020; Dantas et al. 2020; Muhammad et al. 2020; Bashir et al. 2020; Wang et al. 2021) and a decreasing in the noise levels (Zambrano-Monserrate et al. 2020; Aletta et al. 2020) have been proven. An improvement in the water quality of the aquatic ecosystems in terms of physicochemical properties has been also reported in the several studies. For example, during the lockdown period, the suspended particulate matter (SPM) had 15.9\% reduction in the Vembanad Lake, India (Yunus et al. 2020). The values of Biological Oxygen Demand (BOD) and Chemical Oxygen Demand (COD) in Yamuna River, India, have been decreased $42.83 \%$ and $39.25 \%$ respectively (Patel et al. 2020). An improvement in the Dissolved Oxygen (DO) in the Hooghly-Matla estuarine complex, India, was revealed in the range of $12.40-38.54 \%$ (Chakraborty et al. 2020). The water transparency and reflectance in the lagoon of Venice in Italy and Ganga River in India increased due to reduction in traffic and effluents respectively (Braga et al. 2020; Garg et al. 2020). A significant reduction in the pollution of the Ganga River (India), Gomti River (India), and Meriç-Ergene River Basin (Turkey) with heavy metals was also reported during the different lockdowns (Shukla et al. 2021; Khan et al. 2021; Tokatlı and Varol, 2021). In essence, the COVID-induced lockdowns have led to an unintended worldwide experiment on how changes in human behavior patterns affect environmental quality.

Hazardous elements, including heavy metals, are an important class of environmental pollutants. Due to the persistence in natural conditions and toxicity essence, the contamination by hazardous elements in the fluvial ecosystem has raised public and academic concerns (Vu et al. 2017; Sojka et al. 2019). By increasing the rate of population, urbanization, and industrialization, rivers are in danger of the direct discharge of different types of wastes and wastewaters, resulting in being most susceptible to contamination by hazardous elements among freshwater environments (Khan et al. 2017). Hazardous elements can enter the human body via the food chain and accumulate in different tissues, hence resulting to detrimental effects on human health (Chung et al. 2016; Xiong et al. 2021). Long-term exposure to hazardous elements poses non-carcinogenic impacts and permanent disorders in the human body such as hearing, learning, and attention problems and carcinogenic consequences such as skin and lung cancers (Qu et al. 2018). Hazardous elements often come from anthropogenic sources (e.g., the industrial effluents, domestic sewage, and trafficrelated contaminants) (Tchounwou et al. 2012; Kumar et al. 2019; Setia et al. 2020; Karunanidhi et al. 2021; Somma et al. 2021) and natural sources such as weathering and climatic conditions (Kumar et al. 2020; Arya et al. 2019; Yegemova et al. 2018).

During the lockdown period in Iran, activities of industrial, commercial, and urban businesses and public transportation systems almost came to a standstill and urban traffic reduced considerably (Hoseini and Valizadeh, 2021). Likewise, in Rasht City located in the north of Iran, industrial and urban units were almost closed and the urban traffic volume was considerably decreased. Hence, it is expected that the pollution by hazardous elements may lead to change in the urban rivers during the lockdown period. In other words, the restrictions of social and commercial activities lead to reduce the volume of input pollutants and may affect the pollution of urban rivers by hazardous elements. However, to the best of our knowledge, not many published studies have assessed the impact of COVID-induced lockdowns on water pollution by hazardous elements.

Therefore, the main objective of this study is to quantify the effects of the lockdown period on water pollution caused by hazardous elements. This will be accomplished by comparing the level of water pollution and quality, human health risk, and the contribution of pollution sources in both pre-lockdown and post-lockdown periods. In order to conduct a comprehensive evaluation, the Zarjoub River located in Rasht City was selected due to the following reasons (Iran Water Resources Management Company, 2013; Iran Department of Environment, 2005; Ashayeri et al. 2020): (1) the Zarjoub River is exposed to different types of pollution sources including industrial and agricultural effluents as well as hospitals, domestic, and rural solid waste and wastewater, making this river one of the most polluted rivers in Iran (Zolfagharipoor and Ahmadi, 2016); (2) the Zarjoub River plays a critical role in the water supply for agricultural, industrial, and municipal purposes; and (3) the Zarjoub River is economically significant as the main source of irrigation water for more than 230,000 ha of rice paddies in Guilan province, Iran. There is, heretofore, not many information about the status and reaction of aquatic ecosystems in agro-urban areas associated with hazardous elements during the lockdown period. The objectives of this study are as follows: (1) to assess the effects of the COVID-19 lockdown on the quality of a river (the Zarjoub River) that is impacted by a combination of urban and agricultural stressors; (2) to introduce a new index-based graphical approach to reporting the quality of water impacted by hazardous elements; (3) to quantitatively assess how the impact of different stressors on 
the Zarjoub River was altered by the COVID-19 lockdown; and (4) to determine how the COVID-19 lockdown affected the river's suitability as an irrigation source for the region's food crops. Therefore, the results of this study may help to provide a controlling program for similar rivers and may be useful for making remediation decisions.

\section{Materials and method}

\section{Study area}

The Zarjoub river, with a length of $41 \mathrm{~km}$, is located in Guilan province, north of Iran (Fig. 1). After passing through Rasht city, the Zarjoub River reaches the Anzali Lagoon in the southwest of the Caspian Sea. The Zarjoub watershed is characterized by a mild climate with rainy winters and hot-humid summers. The relative humidity in the watershed varies between $55 \%$ in July and $98 \%$ in October. The annual precipitation and temperature in Rasht city are $1402 \mathrm{~mm}$ and $15.8^{\circ} \mathrm{C}$, respectively. In upstream, the lithology of the watershed mainly consists of thick and moderate layers of dark-grey lime. Sedimentary rocks such as limestone, sandstone, and shale can be found in downstream of the watershed. In addition, the present-age sediments in the watershed indicate weathering and erosion as dominant active geomorphological processes in the study area (Monavari et al. 2012; Nematollahi et al. 2018). The watershed is the most populated region in Guilan province with a population of one million inhabitants in the urban and rural areas (Charkhabi et al. 2008). The Zarjoub River becomes highly polluted after absorbing the pollution loads caused by different sources and receiving various waste and wastewaters. In upstream, the Zarjoub River experiences the pollution of the landfill leachate. Approximately 700 tons of daily hospital and domestic wastes are transferred to the landfill without any pre-treatment covered 13 ha of the forest area (Shariatmadari et al. 2018). Due to the wet and humid climate with low frost days, highly toxic leachate at the landfill discharges into the Zarjoub River (Sheijany et al. 2020). In midstream, approximately 500 factories located in the Industrial Rasht City are responsible for discharging a large amount of industrial effluents in the river (Charkhabi et al. 2008). In downstream, the Zarjoub river is polluted by the hospital and domestic wastewater combined with vehicular pollution. In addition, the study area is covered with paddy fields employed for rice cultivation. Due to the precipitation and surface runoff in paddy fields, the agricultural effluents enter the Zarjoub River elevating the level of pollution. The water contamination of the Zarjoub River has directly put the Anzali Lagoon and the Caspian Sea in danger of catastrophic consequences in terms of environmental pollution (Ghodrati et al. 2012).

\section{Sample collection and analysis}

Water sampling of the Zarjoub river was conducted in February and May 2020 representing pre-lockdown and postlockdown periods, respectively. A total of twenty six samples (thirteen samples in February, and thirteen samples in May) were collected in thirteen sites from the upstream to the downstream of the Zarjoub River, as noted in Fig. 1.

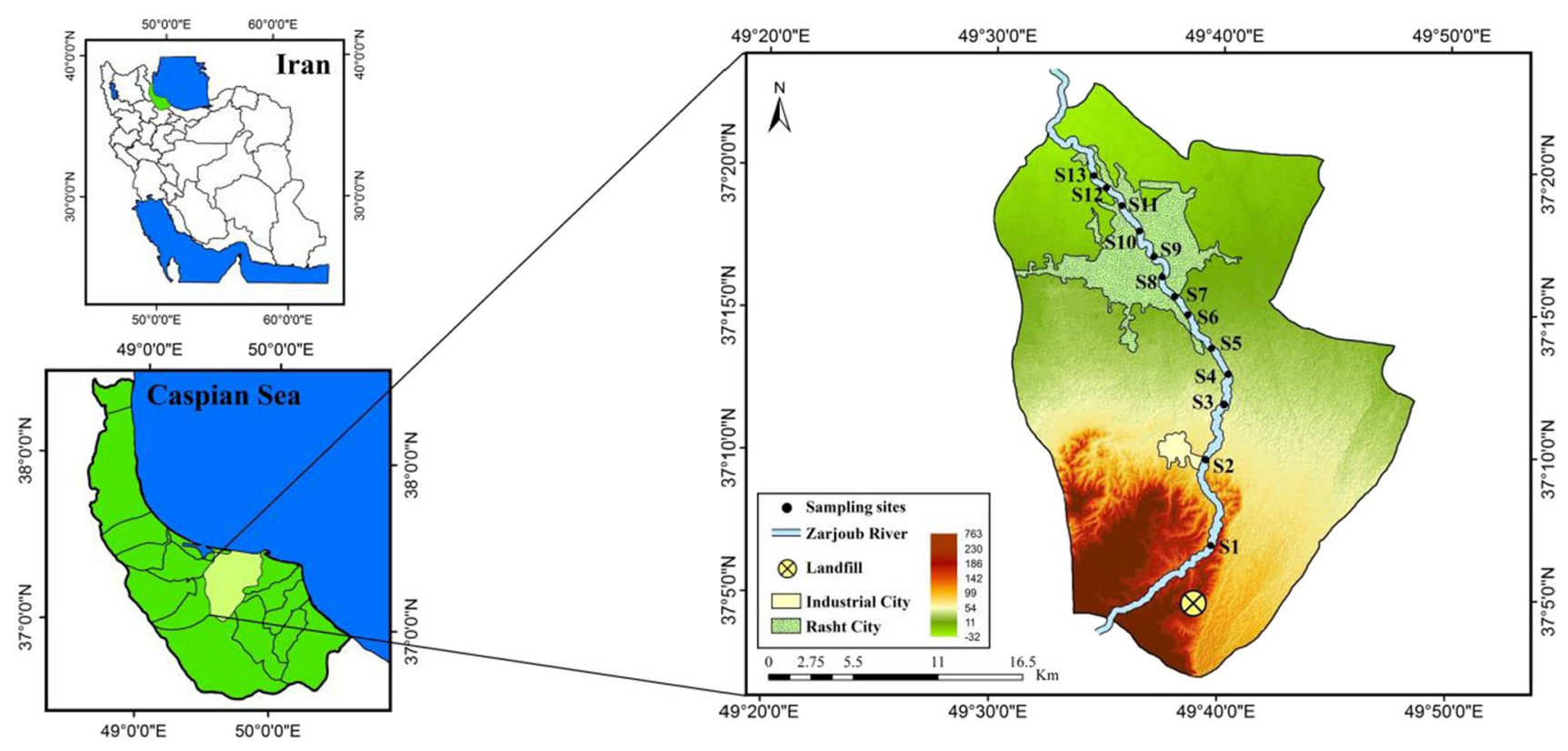

Fig. 1 The study area and the location of sampling sites 
The sampling locations were selected based on the potential sources of pollution with respect to the field observation. The sampling sites S1-S4 were selected for monitoring the landfill site and industrial areas but the sampling sites S5-S13 are related to rural and municipal areas. At each site, the sampling was carried out at a depth of $20 \mathrm{~cm}$ below the surface water. The samples were filtered through a 0.45 $\mu \mathrm{m}$ filter, acidified with the ultra-pure concentrated nitric acid, and were stored in pre-cleaned polyethylene bottles. By using a refrigerator, all samples were transferred to the laboratory at $4{ }^{\circ} \mathrm{C}$ for elemental analysis.

The concentrations of $\mathrm{Al}, \mathrm{As}, \mathrm{Ba}, \mathrm{Cr}, \mathrm{Cu}, \mathrm{Mo}, \mathrm{Ni}, \mathrm{Pb}$, $\mathrm{Se}, \mathrm{Zn}, \mathrm{Na}, \mathrm{Mg}$, and $\mathrm{Ca}$ were measured using inductively coupled plasma mass spectrometry (ICP-MS, Agilent 7700, USA). Acid digestion following by centrifugation was conducted in order to pretreatment of the samples for the ICPMS analysis. Electerical conductivity (EC) was measured using an in situ EC meter (Hanna-HI-98312). The certified reference materials (CRM) obtained from SPEX CertiPrep were used for checking the accuracy of the analysis, and the recovery rates were found in the range of $96-103 \%$. All samples were analyzed in triplicate and the relative standard deviation (RSD) values were obtained $<5 \%$.

\section{Assessment of water pollution}

The concentrations of different elements were measured at thirteen sampling locations in the river, as described above. To understand the implications of the measured concentrations, these concentrations are aggregated into four different indices that have been presented in the prior literature: (1) heavy metal pollution index, $H P I$; (2) heavy metal evaluation index, $H E I$; (3) degree of contamination index, $C_{d e g}$; and (4) water quality index, WQI. Each of these indices provides useful information about the relative importance of the metals present in the river. $W Q I$ is further sub-divided into a water quality index for drinking-water purposes (WQI-Dri), for irrigation purposes (WQI-Irr), and for aquatic life in the river (WQI-Aqu). Finally, the six indices (HPI, HEI, $C_{d e g}$, WQI-Dri, WQI-Irr, and WQI-Aqu) can be analyzed graphically to provide an overall assessment of the quality of the river, as explained in the sub-sections following. The details of indices are provided in Table 1.

\section{Assessment of suitability of water quality for agricultural purposes}

The high concentration of dissolved salts and major cations such as sodium in the water can pose harmful consequences on agricultural soils and plants. It may change the soil characteristics, increase the soil salinity, reduce the soil infiltration and fertility, elevate the level of soil alkalinity, and influence on the growth and nutrients availability for plants
(Hasan et al. 2020; Fallahati et al. 2020; Berhe, 2020). To evaluate the level of salinity hazard in the river, electrical conductivity (EC) according to micro-Mohs/cm in the water was measured in both pre-lockdown and post-lockdown periods. The salinity hazard is grouped into four categories: excellent $(150<\mathrm{EC}<250)$, good $(251<\mathrm{EC}<750)$, doubtful $(751<\mathrm{EC}<2250)$, and unsuitable $(\mathrm{EC}>2250)$ (Islam et al. 2017).

The alkalinity hazard of the water is determined using the sodium absorption ratio (SAR) based on the obtained cations concentration in the water samples as follows (Fallahati et al. 2020):

$S A R=\frac{N a^{+}}{\sqrt{\left(M g^{2+}+C a^{2+}\right)} / 2}$

The alkalinity hazard is also divided into four classes: excellent $(S A R<10)$, good $(10<S A R<18)$, fair $(18<S A R<26)$, and poor $(S A R>26)$ (Ayers and Westcot, 1985; Simsek and Gunduz, 2007). For better understanding the salinity and alkalinity hazards, the US Salinity Laboratory (USSL) diagram was used in which $\mathrm{x}$ axis represents EC and y axis demonstrates SAR values (Sahoo and Khaoash, 2020). In the USSL scatter plot, the classifications of the salinity and alkalinity are expressed by $\mathrm{C}$ and $\mathrm{S}$, respectively. The classification of water quality for irrigation which purpose based on USSL diagram is given in Table S2.

\section{Human health risk assessment}

This section has been described in Supplementary Information (SI).

\section{Multivariate statistical analyses}

To trace the sources of pollution in pre-lockdown and postlockdown periods, principal component analysis (PCA) combined with Pearson's correlation analysis was performed. By demining the inter-relationship of hazardous elements using the correlation matrix, it helps to verify the results of PCA (Gu and Gao, 2018). The descriptive and multivariate statistical analyses were conducted using SPSS 26 (SPSS Inc., USA) software. The normal distribution of data was checked using the Kolmogorov-Smirnov (K-S) test (Sangsefidi et al. 2017; Mehraein et al., 2020; Jaskuła et al., 2021). The validity of PCA results was examined by using Kaiser-Meyer-Olkin (KMO) value (0.521) and Bartlett sphericity tests $(p<0.001)$ and the principal components were extracted by varimax rotation. The multi linear regression (MLR) was applied on the factors obtained by PCA. PCA-MLR as a receptor model quantifies the percentage contribution of pollution sources (Pan et al. 2017). PCAMLR is formulated as follows (Fakhradini et al. 2019): 
Table 1 Mathematical expressions and classification of indices for water pollution by hazardous elements

\begin{tabular}{|c|c|c|c|c|}
\hline Indices & Mathematical expressions & Classification & $\begin{array}{l}\text { Contamination/ } \\
\text { quality } \\
\text { Degree }\end{array}$ & References \\
\hline Heavy metal pollution index (HPI) & $\begin{array}{l}W_{i}=1 / S_{i} \\
Q_{i=\left(\left|M_{i}-I_{i}\right|\left(S_{i}-I_{i}\right) \times 100\right.} \\
H P I=\sum_{i=1}^{i} W_{i} Q_{i} / \sum_{i=1}^{i=n} W_{i} \\
\text { Where } \mathrm{M}_{\mathrm{i}} \text { is the measured concentration of the } \\
\mathrm{i}^{\text {th }} \text { element. } S_{i} \text { and } I_{i} \text { are the standard permis- } \\
\text { sible and the desirable values, respectively, } \\
\text { which were taken from the WHO (2011) and } \\
\text { are provided in Table } \mathrm{S} 1\end{array}$ & $\begin{array}{l}\mathrm{HPI}<15 \\
15<\mathrm{HPI}<30 \\
\mathrm{HPI}>30\end{array}$ & $\begin{array}{l}\text { Low } \\
\text { Medium } \\
\text { High }\end{array}$ & $\begin{array}{l}\text { Edet and Offiong, } \\
\text { (2002); } \\
\text { Qu et al. (2018) }\end{array}$ \\
\hline Heavy metal evaluation index (HEI) & $\begin{array}{l}H E I=\sum_{i=1}^{i=n} M_{i} / M A C \\
\text { Where } M_{i} \text { and } M A C \text { represent the concentration } \\
\text { of } i^{\text {th }} \text { element and the relevant maximum allow- } \\
\text { able concentration, respectively. The values of } \\
M A C \text { were also taken from WHO (2011) and } \\
\text { are shown in Table S1 }\end{array}$ & $\begin{array}{l}\mathrm{HEI}<10 \\
10<\mathrm{HEI}<20 \\
\mathrm{HEI}>20\end{array}$ & $\begin{array}{l}\text { Low } \\
\text { Medium } \\
\text { High }\end{array}$ & $\begin{array}{l}\text { Bodrud-Doza et al } \\
2016\end{array}$ \\
\hline $\begin{array}{l}\text { Degree of contamination index } \\
\left(C_{d e g}\right)\end{array}$ & $\begin{array}{l}C_{f i}=\left(M_{i} / S_{i}\right)-1 \\
C_{d e g}=\sum_{i=1}^{n} C_{f i} \\
\text { Where } M_{i} \text { is the measured concentration of } i^{\text {th }} \\
\text { element, and } S_{i} \text { is the standard permissible } \\
\text { value }\end{array}$ & $\begin{array}{l}C_{d e g}<1 \\
1<C_{d e g}<3 \\
C_{d e g}>3\end{array}$ & $\begin{array}{l}\text { Low } \\
\text { Medium } \\
\text { High }\end{array}$ & $\begin{array}{l}\text { Abdel-Satar et al. } \\
2017\end{array}$ \\
\hline Water quality index (WQI) & 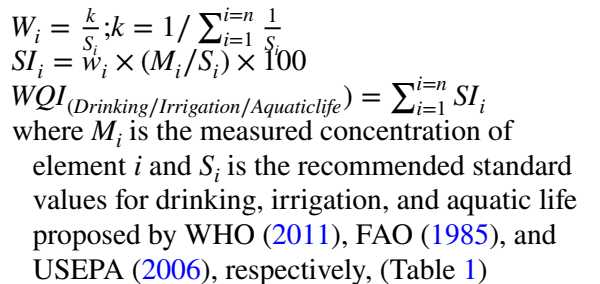 & $\begin{array}{l}W Q I<25 \\
26<W Q I<50 \\
51<W Q I<75 \\
76<W Q I<100 \\
W Q I>100\end{array}$ & $\begin{array}{l}\text { Excellent } \\
\text { Good } \\
\text { Poor } \\
\text { Very poor } \\
\text { Unsuitable }\end{array}$ & $\begin{array}{l}\text { Yadav et al. 2010; } \\
\text { Custodio et al. } \\
2021\end{array}$ \\
\hline
\end{tabular}

$z=\sum_{i-1}^{i-n} B_{i} X_{i}$

$C_{i}(\%)=\frac{B_{i}}{i=n} \times 100$

where $Z$ is the normalized sum of the hazardous elements, $B_{i}$ and $C_{i}$ show the coefficient of the regression for factor $i$ and the contribution of the source $i$.

\section{Results and discussion}

\section{Hazardous elements concentration}

Statistical parameters and the variation of hazardous elements in the pre-lockdown and post-lockdown periods are presented in Table 2 and Fig. S1, respectively. The International Standards for Drinking Water (WHO, 2011), Water Quality for Agriculture (FAO, 1985), and National Recommended Water Quality Criteria-Aquatic Life (USEPA, 2006) are also given for comparison. The results indicated that the mean elemental concentration in pre-lockdown period follows the decreasing order as $\mathrm{Al}(197 \mu \mathrm{g} / \mathrm{L})>\mathrm{Ba}$ $(110 \mu \mathrm{g} / \mathrm{L})>\mathrm{Cr}(56 \mu \mathrm{g} / \mathrm{L})>\mathrm{Zn}(29 \mu \mathrm{g} / \mathrm{L})>\mathrm{Ni}(21 \mu \mathrm{g} / \mathrm{L})>\mathrm{Pb}$ $(15 \mu \mathrm{g} / \mathrm{L})>\mathrm{Cu}(5.2 \mu \mathrm{g} / \mathrm{L})>\operatorname{Se}(4.8 \mu \mathrm{g} / \mathrm{L})>$ As $(3.2 \mu \mathrm{g} / \mathrm{L})$. However, a descending order of the mean concentration was observed in the post-lockdown period as follows: $\mathrm{Ba}(108 \mu \mathrm{g} / \mathrm{L})>\mathrm{Al}(93 \mu \mathrm{g} / \mathrm{L})>\mathrm{Zn}(39 \mu \mathrm{g} / \mathrm{L})>\mathrm{Ni}$ $(31 \mu \mathrm{g} / \mathrm{L})>\mathrm{Cr}(24 \mu \mathrm{g} / \mathrm{L})>\mathrm{Pb}(14 \mu \mathrm{g} / \mathrm{L})>\mathrm{As}(3.6 \mu \mathrm{g} / \mathrm{L})>\mathrm{Se}$ $(2.7 \mu \mathrm{g} / \mathrm{L})>\mathrm{Cu}(1.1 \mu \mathrm{g} / \mathrm{L})$. Comparing with the national and international guidelines, the mean concentrations of all elements in pre-lockdown period were less than the standard values recommended by WHO (2011) for drinking purposes except for $\mathrm{Cr}$ and $\mathrm{Pb}$. In post-lockdown period, only $\mathrm{Pb}$ had a concentration higher than the standard value. For irrigation purposes, the mean value of $\mathrm{Ba}$ in both pre-lockdown and post-lockdown periods was measured higher than standard values proposed by FAO, 1985). In addition, the mean value of $\mathrm{Cr}$ exceeded the permissible value for aquatic life recommended by USEPA (2006) for both pre-lockdown and post-lockdown periods. The values exceeded WHO (2011) standard for $\mathrm{Al}, \mathrm{Cr}$, and $\mathrm{Pb}$ in $20 \%, 70 \%$, and $100 \%$ of prelockdown period samples, respectively. In the post-lockdown period, only $\mathrm{Pb}$ exceeded WHO standard and was measured 
Table 2 Statistical summary of hazardous elements in the Zarjoub River (unit, $\mu \mathrm{g} / \mathrm{L}$ )

\begin{tabular}{llllllllllll}
\hline & $\mathrm{Al}$ & $\mathrm{As}$ & $\mathrm{Ba}$ & $\mathrm{Cr}$ & $\mathrm{Cu}$ & $\mathrm{Mo}$ & $\mathrm{Ni}$ & $\mathrm{Pb}$ & $\mathrm{Se}$ & $\mathrm{Zn}$ \\
\hline Pre-lockdown & Mean & 197 & 3.2 & 110 & 56 & 5.2 & 5.7 & 21 & 15 & 4.9 & 29 \\
& $\mathrm{SD}$ & 14.4 & 0.16 & 5.33 & 9.03 & 0.50 & 1.22 & 2.86 & 0.85 & 0.55 & 3.06 \\
& Minimum & 170 & 3.0 & 100 & 44 & 4.4 & 4.1 & 18 & 14 & 3.9 & 24 \\
& Maximum & 220 & 3.6 & 122 & 72 & 6.3 & 8.9 & 26 & 16 & 5.9 & 36 \\
Post-lockdown & Mean & 93 & 3.6 & 108 & 24 & 1.1 & 3.9 & 31 & 14 & 2.7 & 39 \\
& SD & 21.7 & 0.56 & 5.96 & 3.86 & 0.16 & 0.26 & 0.94 & 0.07 & 1.38 & 1.48 \\
& Minimum & 70 & 2.6 & 92 & 15 & 0.7 & 3.6 & 29 & 14 & 1.1 & 38 \\
& Maximum & 130 & 4.6 & 117 & 32 & 1.3 & 4.3 & 32 & 15 & 6.4 & 43 \\
WHO, (2011) & & 200 & 10 & 700 & 50 & 2000 & 70 & 70 & 10 & 10 & 3000 \\
FAO, (1985) & & 5000 & 100 & 100 & 100 & 200 & 10 & 200 & 5000 & 20 & 2000 \\
USEPA, (2006) & & 750 & 340 & - & 16 & 13 & - & 470 & 65 & - & 120 \\
\hline
\end{tabular}

to be above that standard in $100 \%$ of samples collected. In addition, Ba showed a higher concentration with respect to the value of FAO (1985) in 90\% of samples in both prelockdown and post-lockdown periods. Furthermore, the concentration of $\mathrm{Cr}$ in $100 \%$ of pre-lockdown period samples and $90 \%$ of post-lockdown period samples were found to be more than the standard value of USEPA (2006).

According to Fig. S1, it is clear that the mean concentrations of $\mathrm{Al}, \mathrm{Cr}, \mathrm{Cu}, \mathrm{Mo}$, and $\mathrm{Se}$ were reduced in the post-lockdown period as compared to pre-lockdown period. The mean values of $\mathrm{As}, \mathrm{Ba}$, and $\mathrm{Pb}$ were not significantly different whereas $\mathrm{Ni}$ and $\mathrm{Zn}$ in post-lockdown period were higher than those in pre-lockdown period. These findings revealed that the lockdown period has had a great impact on river pollution caused by hazardous elements.

\section{Hazardous elements pollution during lockdown period}

The longitudinal trends of pollution indices during the two periods are presented in Fig. 2a-c. The results of HPI and $C_{d e g}$ indicate that the level of pollution in the pre-lockdown period would be categorized as high, whereas in the post-lockdown period, the pollution level would be categorized in the medium range. Considering all sampling sites, the mean values of $H P I$ decreased from 36 to 22 and $C_{d e g}$ decreased from 3.9 to 2.3 from the pre-lockdown period to post-lockdown period. These results indicate a $38 \%$ and $41 \%$ reduction in the extent of pollution, respectively, caused by the lockdown period. Compared to HPI and $C_{d e g}$, the $H E I$ values presented a lower level of pollution for the pre-lockdown. Although the mean values of $H E I$ reduced $11 \%$ in the level of contamination, the $H E I$ index showed medium contamination in both pre-lockdown and post-lockdown periods.

Longitudinal trends of water quality indices are presented in Fig. 2d,e. The water quality index for drinking usages displayed poor water quality for both pre-lockdown and post-lockdown periods. However, the mean values of WQI-Dri were calculated 73 and 62 in the pre-lockdown and post-lockdown periods, respectively. It reveals that drinking water quality improved $15 \%$ during the lockdown period. Longitudinal trends show that, at the beginning of the urban areas, water quality was very poor in the prelockdown period that it might be due to the contamination by wastewater. For both pre-lockdown and post-lockdown periods, the water quality is good for irrigation purposes. The mean values of WQI-Irr decreased from 45 to 32 and recorded a $29 \%$ improvement in irrigation water quality in the post-lockdown period with respect to the pre-lockdown period. Regarding aquatic life status, the water quality index presented an unsuitable level in the pre-lockdown period and the river was unfit for living aquatic organisms, while it improved to poor water quality in the post-lockdown period. Taking into consideration all sampling sites, the mean values of WQI-Aqu were found 141 and 62 in the pre-lockdown and post-lockdown periods, respectively. It showed that in the lockdown period, the water quality for aquatic life improved by approximately 58\%. According to the results of the longitudinal trends, the values of pollution increased in the urban area (sampling sites 6-13). Although the water quality for drinking and aquatic life improved in the post-lockdown period, the water quality is still poor. This is associated with the high concentration and contribution of elements in the urban area mainly originating from anthropogenic activities.

\section{Safe-Heart indicator}

The concept of heart-shaped graph is a useful visual approach for the overall assessment of the water pollution. Sakai et al. (2018) suggested a heart-shaped graph named the Eco-Heart indicator for evaluation of physicochemical parameters in water. Conforming to the results of indices in this study, the concept of the Safe-Heart indicator was 


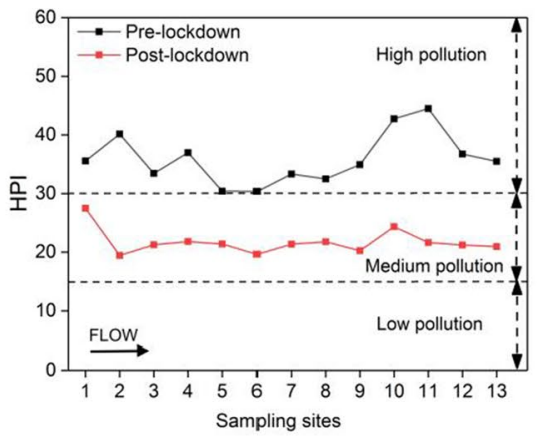

(a)

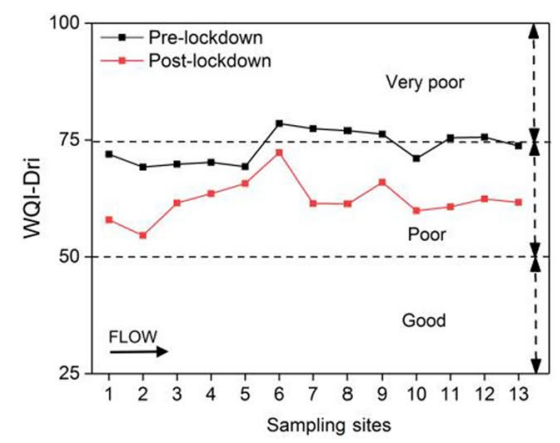

(d)

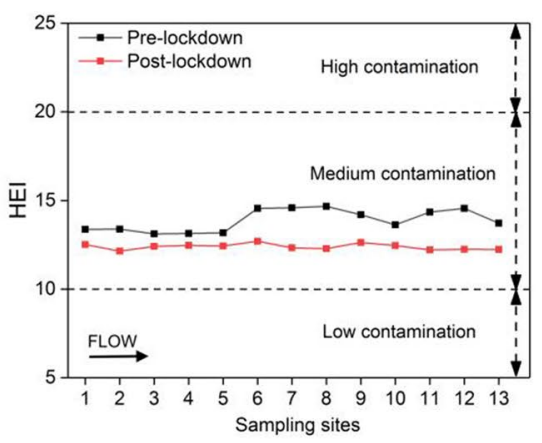

(b)

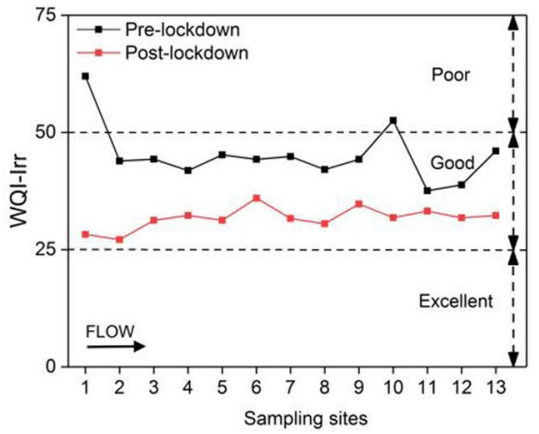

(e)

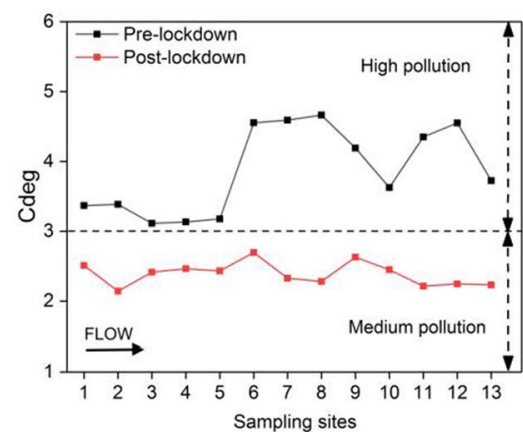

(c)

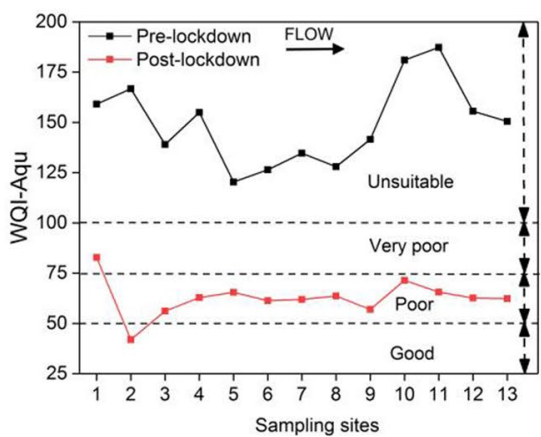

(f)

Fig. 2 Water pollution and quality indices values plotted by site from upstream (1) to downstream (13)

developed for the first time to evaluate water pollution using indices. The Safe-Heart indicator is based on a radar chart with six axes representing the value of indices. All indices start from the edge of the axes except for $\mathrm{C}_{\mathrm{deg}}$ for shaping the heart. The critical values of indices were determined as $15,10,1,40,40$, and 40 for HPI, HEI, $C_{d e g}$, WQI-Dri, WQI$I r r$, and WQI-Aqu, respectively. These values were marked in the axes and the consecutive axes were connected to each other using a curve line. Eventually, a perfect heart-shape graph would indicate an ideal situation of the water in terms of contamination by hazardous elements (light red plot in Fig. 3). If one or more indices exceed the relevant critical value, a deformed-heart shape becomes visible and the shape will get distorted. The Safe-Heart graphs for the average concentration of hazardous elements in the pre-lockdown and post-lockdown periods are depicted in Fig. 3.

According to the mean values of indices, an irregular heart-shape appeared in the pre-lockdown period indicating excessive pollution of water by hazardous elements. However, an improvement in the shape of the heart (particularly in the lower half of the heart) was observed in the post-lockdown period, demonstrating that the status of pollution in the water got better during the lockdown period. In Fig. 3, the sampling sites 1, 2, and 10 were selected for the evaluation of the Safe-Heart which represent three major sources of pollution including landfill, industrial city, and urban area respectively. The results of Fig. 3 showed that the pollution in the urban and industrial area has a severe role on the deformation of the heart in the pre-lockdown period followed by landfill site. The three sampling sites illustrated an improvement in the shape of the hearts in the post-lockdown period. In site 2 , the most improvement was observed which is due to a great reduction in effluents released by the industrial city in the lockdown period. In sites 1 and 10, the values of $H P I$ and WQI-Aqu were calculated higher than site 2 in the post-lockdown period. Therefore, the shape of the heart in site 1 and 10 shows a deviation to the center of the graph on the right and left sides. Accordingly, it can be inferred that the reduction of industrial activities has had significant impact on water quality during the lockdown period.

\section{Multivariate statistical analysis}

Principal component analysis (PCA) and Pearson's correlation analysis were conducted to identify the association between hazardous elements and possible sources of pollution. The results of PCA in the pre-lockdown period are given in Fig. 5a and Table S4. Three principal components 


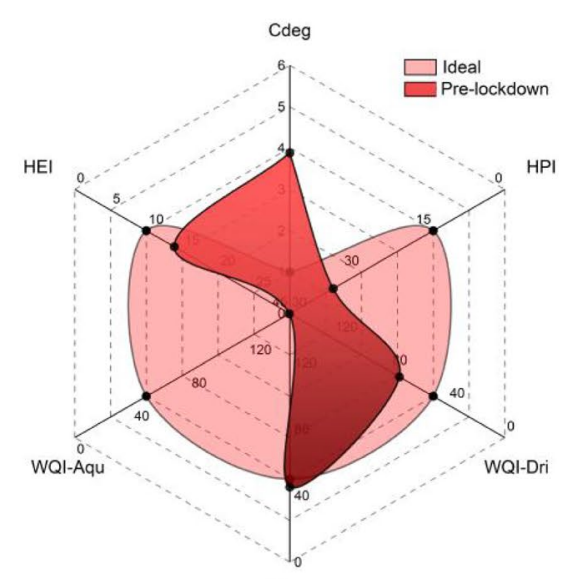

WQI-Irr

Mean values of indices

for pre-lockdown

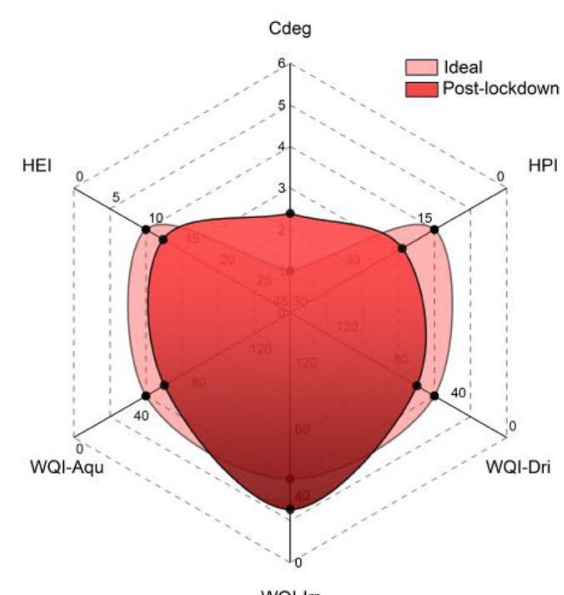

Mean values of indices

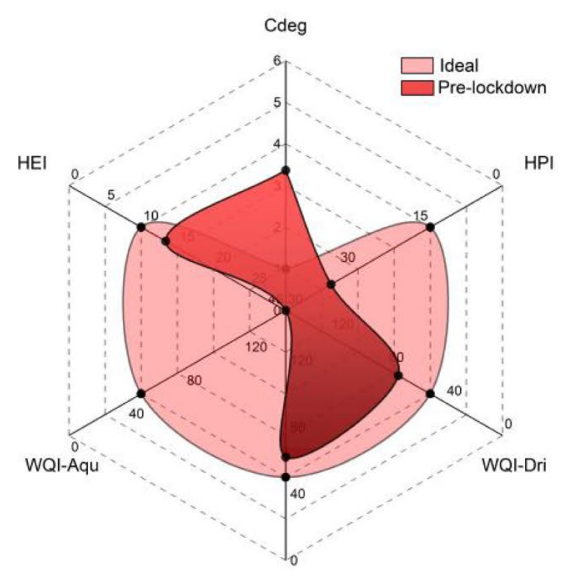

WQI-Irr

S1-Pre-lockdown

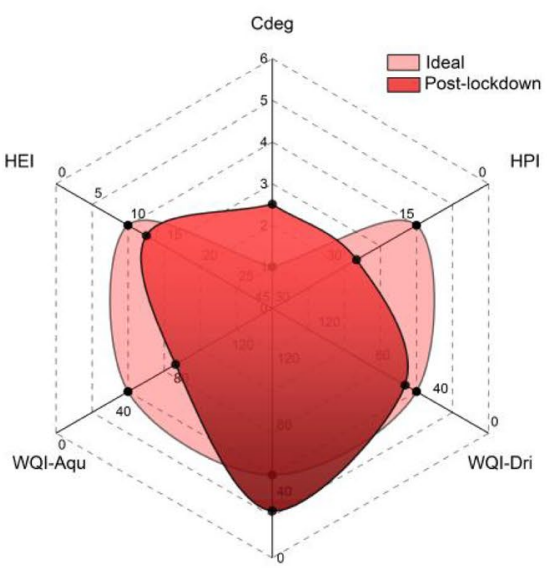

WQI-Irr

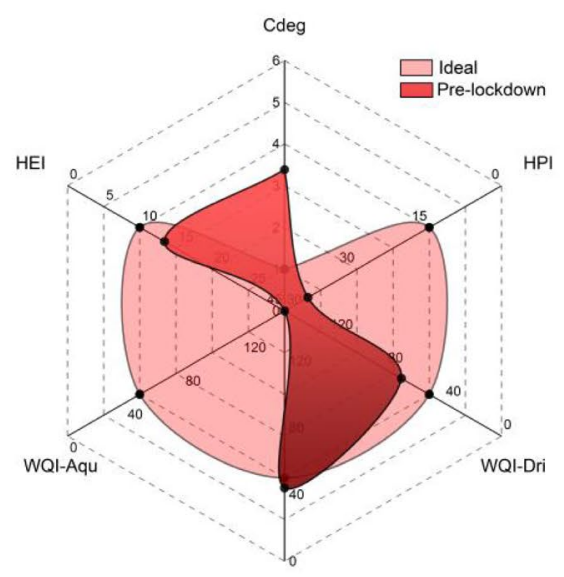

WQI-Irr

S2-Pre-lockdown

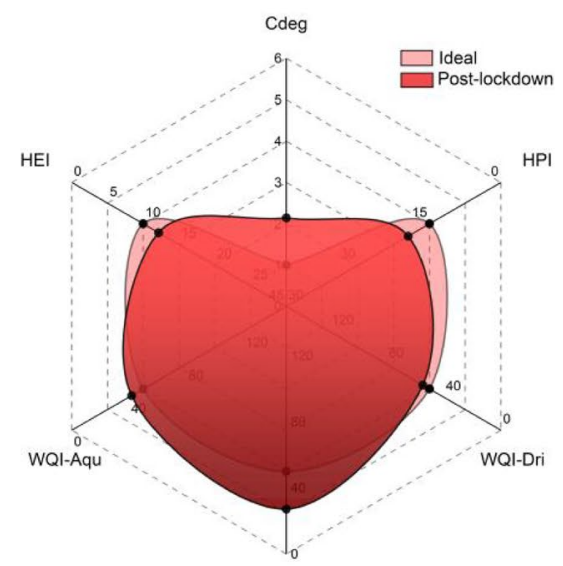

WQI-Irr

S2-Post-lockdown

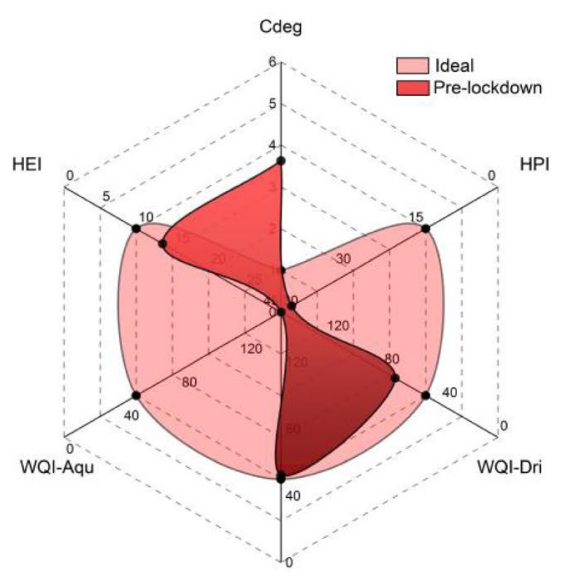

WQI-IrT

S10-Pre-lockdown

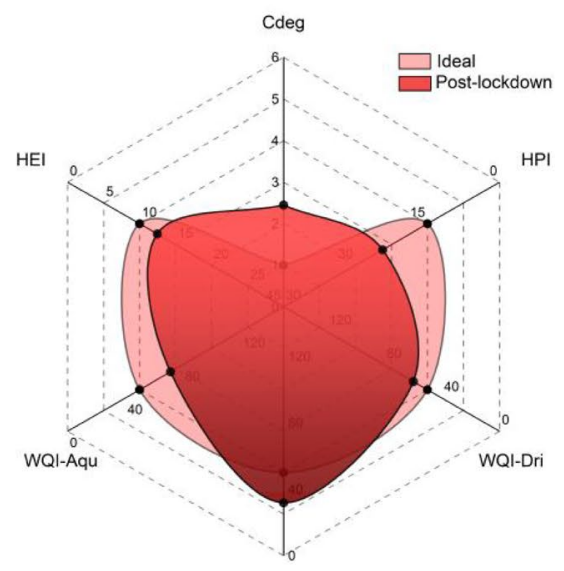

WQI-Irr

S10-Post-lockdown

Fig. 3 Comparison of the Safe-Hearts based on the mean values of indices and major sampling sites 
with eigenvalues greater than one were extracted, describing about $76 \%$ of the total variance. As, $\mathrm{Ba}, \mathrm{Mo}, \mathrm{Ni}$, and $\mathrm{Pb}$ demonstrated a high loading in PC1 with $40 \%$ of the total variance. Conforming to the correlation analysis in prelockdown period presented in Fig. 4a , the correlations of these elements reveal a mixed source of pollution including geological and anthropogenic sources. The moderate correlation was observed between $\mathrm{Ba}$ and $\mathrm{Mo}(r=-0.638)$; $\mathrm{Ba}$ and As $(r=0.509)$; indicating that As, Ba, and Mo may originate from weathering of parent materials in the earth's crust (Giri and Singh, 2015; Zeng et al. 2019). However, the moderate correlation between $\mathrm{Ni}$ and $\mathrm{Pb}(r=0.664)$ shows anthropogenic source due to the discharge of the municipal wastewater (Vu et al. 2017; Ustaoğlu and Islam, 2020).

The second component (PC2) explained 23\% of the total variance and specified by $\mathrm{Al}, \mathrm{Cr}, \mathrm{Cu}, \mathrm{Mo}$, and $\mathrm{Se}$. The correlation analysis illustrates a moderate correlation between $\mathrm{Al}$ and $\mathrm{Cr}(r=0.644) ; \mathrm{Al}$ and $\mathrm{Cu}(r=-0.679) ; \mathrm{Al}$ and $\mathrm{Se}$ $(r=-0.538)$. In addition, a relatively moderate correlation was observed between $\mathrm{Mo}$ and $\mathrm{Cu}(r=0.443)$. The correlation among these elements implies that they originate from mixed anthropogenic inputs including industrial effluents and landfill leachate. For example, the effluents of aluminum, smelting, electroplating, and pharmaceutical factories in the industrial city of Rasht might be the sources of $\mathrm{Al}, \mathrm{Cu}, \mathrm{Cr}$, and Se (Wang et al. 2013; Giri and Singh, 2014). Several studies also reported that $\mathrm{Al}, \mathrm{Cr}$, and $\mathrm{Cu}$ can be associated with domestic and hospital solid wastes (Kuo et al., 1999; Saffarzadeh et al. 2016; Nguyen et al. 2020; Liang et al. 2020). According to the field observation, the high concentration of these elements in the urban area implies direct dumping of solid waste into the river (Ghodrati et al. 2012). The third component (PC3) illustrated $13 \%$ of the total variance and dominated by $\mathrm{Cr}$ and $\mathrm{Zn}$. These elements indicated a moderate correlation $(r=-0.549)$ and may be derived from vehicular pollution. The exhaust fumes, coal combustion, abrasion of vehicular tires, and brakes represent the sources of $\mathrm{Cr}$ and $\mathrm{Zn}$ (Duodu et al. 2016; Xiao et al. 2019).

The results of the statistical analyses for post-lockdown period are given in Fig. 4b, 5b, and Table S4. Three principal components were derived and described by $70 \%$ of the total variance. The high loading elements in PC1 viz. As, Ba, Mo, $\mathrm{Ni}$, and $\mathrm{Pb}$ which present $32 \%$ of the total variance have not changed in the post-lockdown period. The correlation analysis also demonstrated an inter-relationship between these elements which is attributed to the weathering combined with discharging of the municipal wastewater. The second component (PC2) explained $22 \%$ of the total variance and specified by $\mathrm{Al}, \mathrm{Cr}, \mathrm{Cu}$, and $\mathrm{Ni}$. According to the correlation matrix, $\mathrm{Cr}$ was moderately correlated with $\mathrm{Ni}(r=-0.554)$. Besides, $\mathrm{Al}$ and $\mathrm{Cu}(r=0.482), \mathrm{Cr}$ and $\mathrm{Cu}(r=0.469)$ illustrated relatively moderate correlations, confirming the associations between these elements. Similar to the source of $\mathrm{Al}, \mathrm{Cr}$, and $\mathrm{Cu}$ in $\mathrm{PC} 2$ of the pre-lockdown period, they may be related to the residual effects of industrial effluents as well as solid wastes in the post-lockdown period. $\mathrm{Ni}$ is also associated with dumping of solid waste and leachate of the landfill (Yusof et al. 2009; Islam et al. 2018).

The third component (PC3) indicated $16 \%$ of the total variance and included Se and $\mathrm{Zn}$ with moderate correlation $(r=0.667)$. This signified a mixed vehicular emissions and agricultural effluents. As discussed, $\mathrm{Zn}$ were considered as a traffic-related source in this area. In addition, the chemical fertilizers were used from the late winter season to the early spring season (lockdown period) for rice cultivation in the study area. Accordingly, the presence of Se and $\mathrm{Zn}$ in the post-lockdown period can be justified with the use of fertilizers and runoff of agricultural wastewater in the prelockdown period. Previous studies have also reported that the agricultural inputs caused by the application of chemical fertilizers, pesticides, and fungicides are the most important sources of Se and Zn (Wang et al. 2011; Zhang et al. 2018; Liang et al. 2020).

To determine the relative significance of pollution sources, multi linear regression (MLR) was applied to the factor scores of PCA analysis. The results of source apportionment using PCA-MLR receptor model are shown in Fig. 5(c and d). According to the results of the pre-lockdown period, $64 \%$ of total hazardous elements are ascribed to the mixed source of industrial effluents and solid waste. The weathering/municipal wastewater and vehicular pollution are dominated by $23 \%$ and $13 \%$ of the contribution, respectively. As discussed, during the lockdown period, industrial activities in the study area were almost shut down with the exception of essential products. Further, vehicular travel was greatly reduced due to social and occupational restrictions. Hence, the sources associated with the industry, transportation, and commuting decreases significantly in the potential sources of pollution in the post-lockdown period. According to the results of PCA-MLR receptor model in the post-lockdown period, the contribution of weathering/ municipal wastewater was almost doubled and took the first place of sources with $50 \%$ of the contribution. The increase of contribution for municipal wastewater may be associated with changes in sanitary behaviors (e.g., hand and face washing and showering) during the lockdown period which leads to an increase in the generation of domestic wastewater (Kataki et al. 2020; Rohila, 2020). Moreover, the number of patients in hospitals increased drastically due to the excessive infection with coronavirus resulting in increased delivery of wastewater from hospitals. The mixed industrial effluents and solid waste pollution also decreased to $45 \%$ of the contribution. Although the discharging of industrial effluents significantly diminished, the amount of solid waste increase during to lockdown period, leading to 
Fig. 4 Pearson's correlation analyses. (a) Pre-lockdown period, and (b) post-lockdown period (bold values refer to coefficients greater than 0.5 )

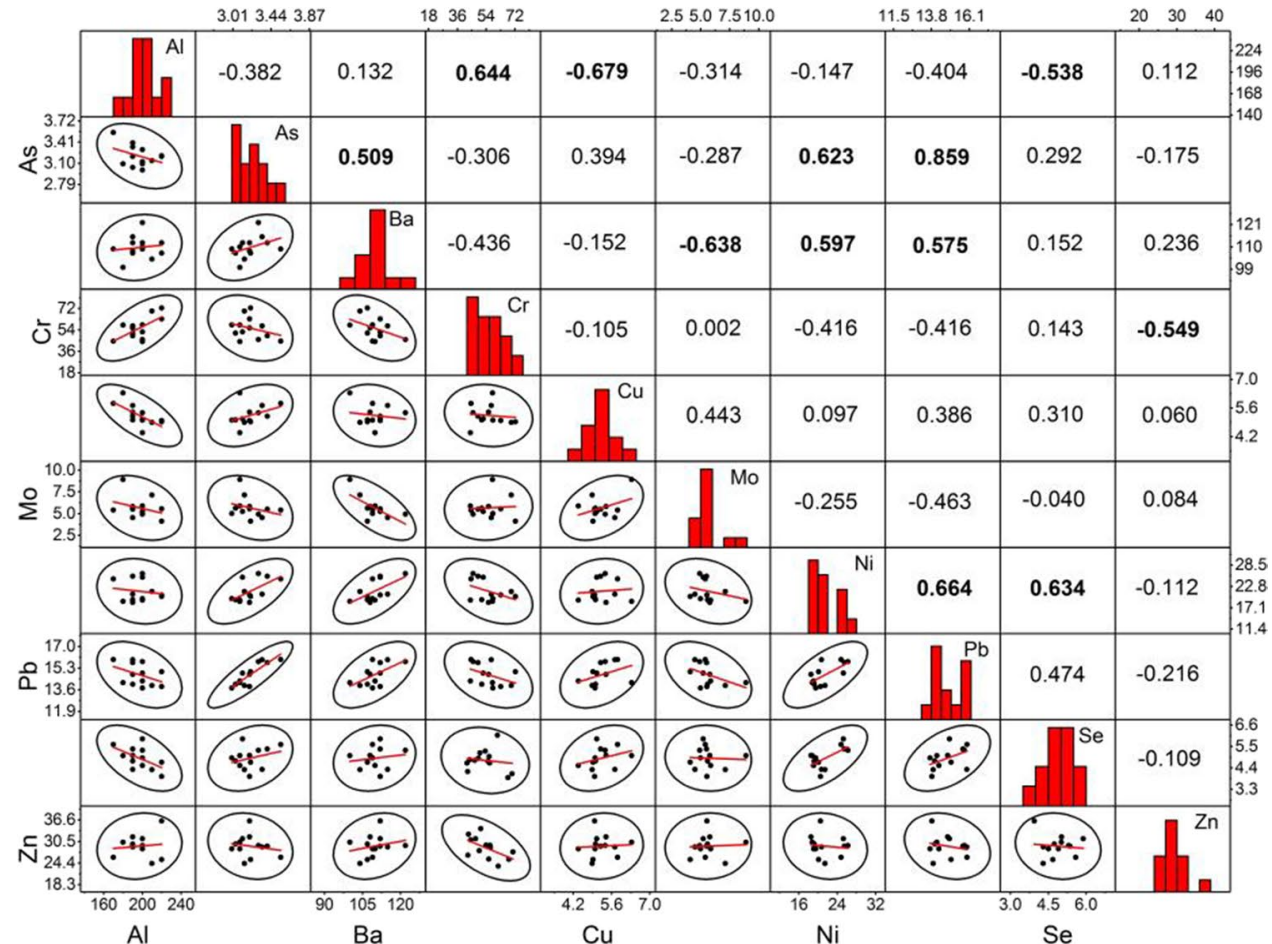

(a)

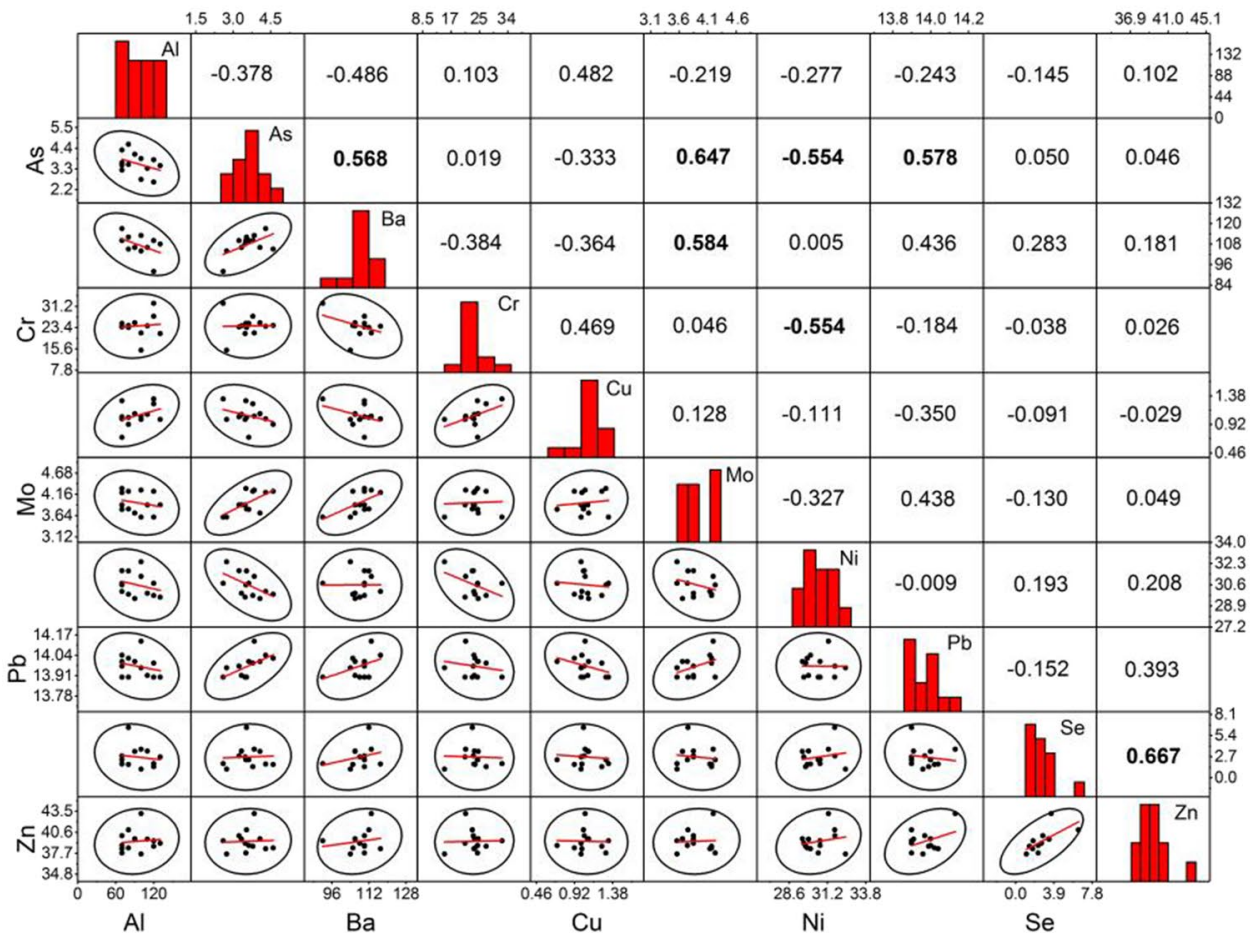

(b) record a 45\% of contribution. According to Vanapalli et al. (2020) and Mostafa et al. 2021, the lockdown period affected the amount of household solid wastes by increasing the use of protection equipment (e.g., facemasks, shield, gowns, gloves, etc.), foods with plastic packages, and disposable utensils. Ilyas et al. (2020) and Kargar et al. (2020) also reported that medical waste generated by infected patients increased dramatically during the lockdown period. The above findings can be attributed to the hyper-hygienic lifestyle during the pandemic. Therefore, the increase in $\mathrm{Ni}$ 


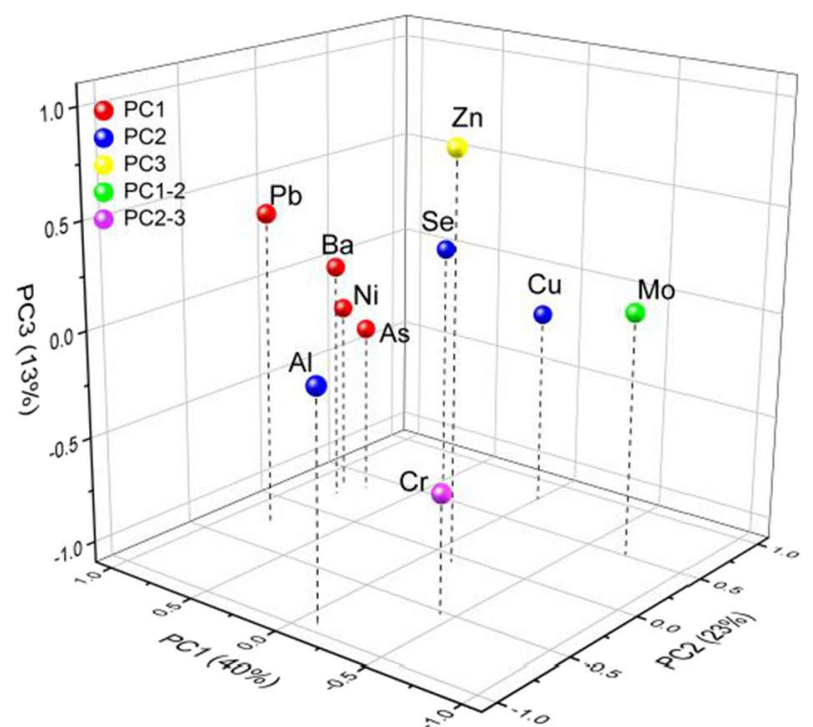

(a)

Weathering / Municipal wastewater Industrial effluents / Solid waste Vehicular pollution

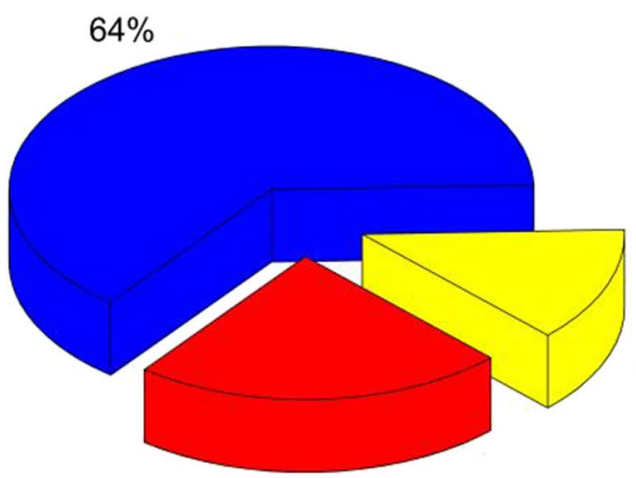

$23 \%$

(c)

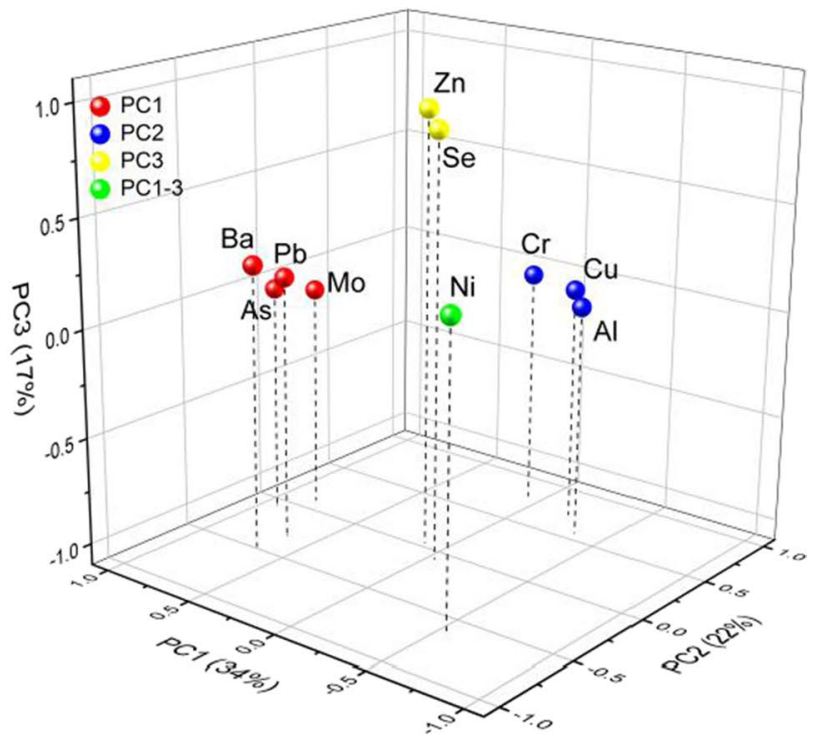

(b)

Weathering / Municipal wastewater Industrial effluents / Solid waste Vehicular pollution/ Agricultural activities

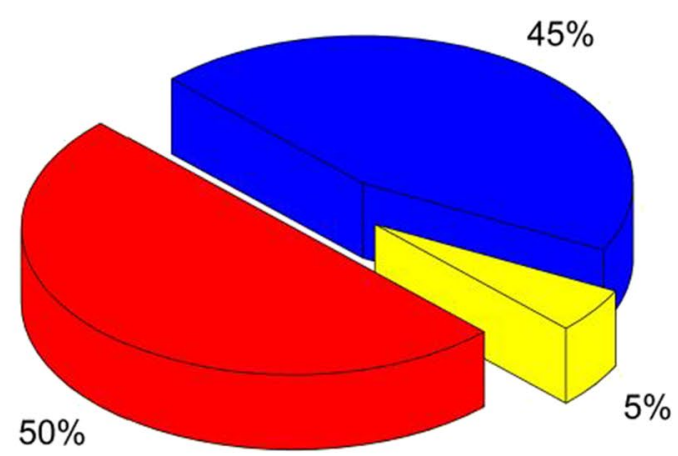

(d)

Fig. 5 (a) PCA for pre-lockdown, (b) PCA for post-lockdown, (c) PCA-MLR receptor model for pre-lockdown, and (d) PCA-MLR receptor model for post-lockdown

concentration during the lockdown period may be justified by increasing the volume of municipal waste and wastewater together with the reduction of rainfall and river discharge (Olias et al. 2004). According to the bulletins of Guilan province weather, the value of precipitation in May illustrated, on average, a 35\% reduction compared with that of in February (Guilan Meteorological Organization, 2020). The rain gauge stations in Rasht City showed that the values of precipitation decreased from 105.3 to $58 \mathrm{~mm}$ in in agricultural station and 91.5 to $68 \mathrm{~mm}$ in airport station during the lockdown period (Table S5). This may also have amplified the concentration of $\mathrm{Ni}$ in the post-lockdown period. The last contribution (5\%) belongs to the vehicular pollution together with agricultural activities as a new source of pollution appeared the post-lockdown period. The concentration of $\mathrm{Zn}$ increased $10 \mu \mathrm{g} / \mathrm{L}$ in the post-lockdown period (Table 2) which may be associated with the agricultural effluents and hydrological impacts due to the season change. 


\section{Human health risk assessment}

The results of human health risk assessment have been described in Supplementary Information (SI).

\section{Cation-based assessment of water}

The statistical data of the agricultural parameters including $\mathrm{Na}^{+}, \mathrm{Mg}^{+2}, \mathrm{Ca}^{+2}, \mathrm{SAR}$, and EC are summarized in Table 3. The results showed that the values of the parameters increased during the lockdown period. The concentration of $\mathrm{Na}^{+}, \mathrm{Mg}^{+2}, \mathrm{Ca}^{+2}, S A R$, and EC in the pre-lockdown period was measured 5.7, 1.6, 2.1, 4, and 1.2 times higher than those in the pre-lockdown period.

Compared to the references, the mean values of $S A R$ in the pre-lockdown period were in the range of excellent water and the value of EC categorized as doubtful water for agricultural purposes in the pre-lockdown and postlockdown periods. Considering the values of $S A R$ and EC, the alkalinity and salinity increased during the lockdown period. The USSL diagram is applied to appraise the status of sodium hazard together with salinity hazard in water samples (Fig. 6a) (Xiao et al. 2021). In the pre-lockdown period, the sampling sites 1,2 , and 3 are categorized as $\mathrm{C} 2 \mathrm{~S} 1$, indicating a little salty and almost good water for irrigation. The other sampling sites exhibited C3S1 which is classified as salty but usable for agriculture. In the postlockdown period, the sampling sites 1 categorized as $\mathrm{C} 2 \mathrm{~S} 1$ while the other sites fell within C3S1, demonstrating a little salty for site 1 and salty for the other sites. As the results shown in Fig. 6b the values of SAR and EC illustrated an increasing trend from upstream to downstream in particular for post-lockdown period. The natural and anthropogenic sources such as weathering and wastewaters lead to increase the level of cations concentration and EC value (Alobaidy et al. 2010; Morrison et al. 2001; Gyimah et al. 2020). In addition, increasing sodium directly increases electrical conductivity (Rao and Nageswararao, 2010). Hence, it can be inferred that municipal wastewater in the study area had the
Table 3 Statistical summary of the agricultural parameters of water in the Zarjoub River

\begin{tabular}{lllllll}
\hline & & $\mathrm{Na}^{+}(\mathrm{meq} / \mathrm{L})$ & $\mathrm{Mg}^{2+}(\mathrm{meq} / \mathrm{L})$ & $\mathrm{Ca}^{2+}(\mathrm{meq} / \mathrm{L})$ & $\mathrm{SAR}$ & $\mathrm{EC}(\mu \mathrm{S} / \mathrm{cm})$ \\
\hline Pre-lockdown & Mean & 0.89 & 0.69 & 1.48 & 0.84 & 952.4 \\
& $\mathrm{SD}$ & 0.25 & 0.11 & 0.29 & 0.2 & 226.7 \\
& Minimum & 0.32 & 0.42 & 0.87 & 0.39 & 476.4 \\
& Maximum & 1.05 & 0.77 & 1.73 & 0.96 & 1166.2 \\
Post-lockdown & Mean & 5.08 & 1.13 & 3.17 & 3.41 & 1113.8 \\
& SD & 1.75 & 0.19 & 0.27 & 1.12 & 220.0 \\
& Minimum & 0.46 & 0.74 & 2.48 & 0.36 & 619.4 \\
\hline
\end{tabular}

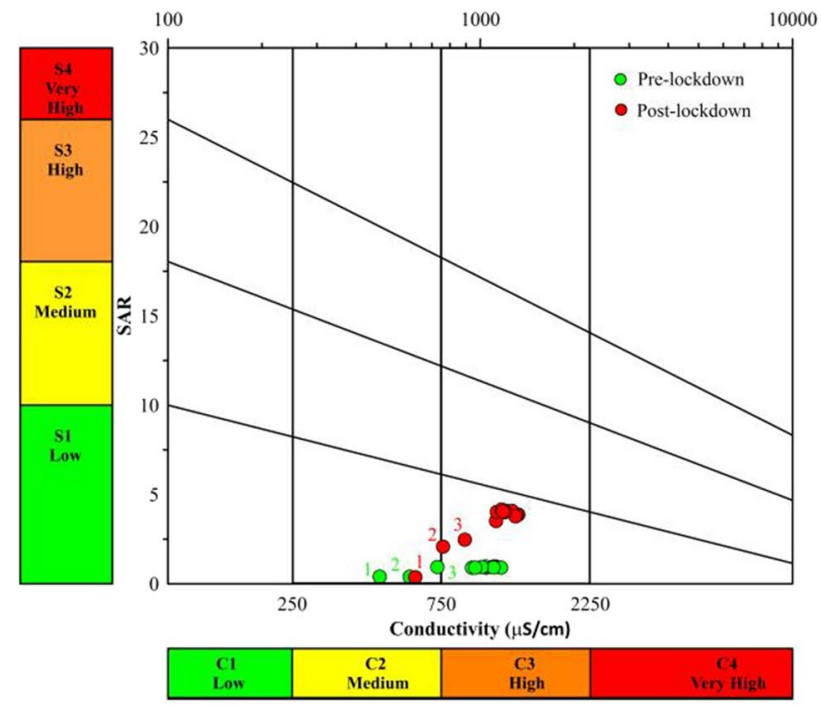

(a)

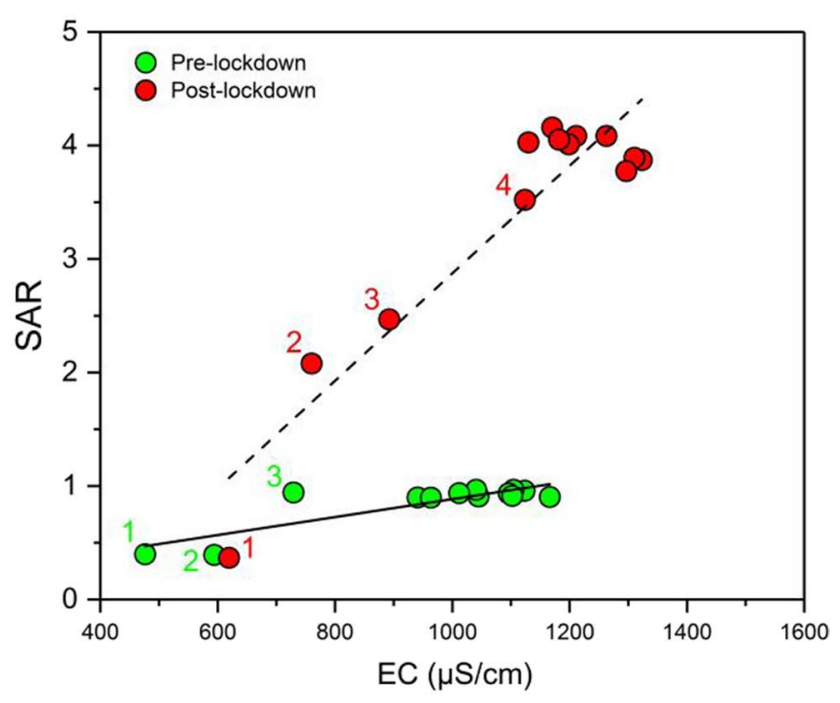

(b)

Fig. 6 (a) The classification of irrigation water based on USSL diagram. (b) The relationship between SAR and EC 
greatest influence on the increase of SAR and EC in postlockdown period.

Besides the discussed sources, the increased value of $\mathrm{Na}^{+}$ in the post-lockdown period may be attributed to the effluents of detergent and disinfectant production units which include sodium hypochlorite $(\mathrm{NaOCl})$. This is one of the cheapest and most accessible disinfectants that has been widely used in the disinfection of hospitals and household surfaces and equipment against coronavirus (Nickmilder et al. 2007; Pereira et al. 2015). The use of sodium hypochlorite disinfectant increased in the hospitals and residential houses recommended by WHO due to the COVID-19 pandemic (Marnie and Peters, 2020; Nabi et al. 2020). According to the news during the lockdown period, the production capacity of the sodium hypochlorite in factories of Rasht City increased 35\% around the clock. Due to the direct discharge of domestic and hospital wastewater into the river, this results in the increase of sodium concentration in the river during the lockdown period. It should be noted that the use of fertilizers in the paddy fields in the pre-lockdown period may increase the cations concentration in the postlockdown period due to the runoff process. Therefore, in the pre-lockdown period, the cations concentration and EC value are associated with natural and anthropogenic sources. It is noteworthy that the flow discharge may affect the level of cations concentrations. The cations concentration decreased by the rainfall due to dilution effect (Hung et al. 2020; Puczko and Jekatierynczuk-Rudczyk, 2020). Accordingly, the low concentration of cations in the prelockdown period can be associated with the rainfall effect. In the post-lockdown period, natural sources, anthropogenic activities, and reduction of the rainfall lead to increase the cations concentration and EC values.

\section{Conclusion}

In the present study, the effects of the lockdown period caused by COVID-19 on the water pollution and quality of the Zarjoub River in the north of Iran in terms of hazardous elements and major cations were evaluated. The main results are as follows:

1- The level of water pollution assessed by HPI, HEI, and $C_{d e g}$ models indicated $38 \%, 11 \%$, and $41 \%$ reduction respectively. In addition, multi-purpose water quality assessment for drinking, irrigation, and aquatic life revealed an improvement by 15\%, 29\%, and 58\% respectively. Although the water quality indices represented an improvement during the lockdown period, poor water quality for drinking purpose and aquatic life was observed in the post-lockdown.
2- According to the results of multivariate statistical analyses and PCA-MLR receptor model, mixed weathering and municipal wastewater were detected as sources of pollution in both pre-lockdown and post-lockdown periods with $23 \%$ and $50 \%$ of the contribution, respectively. The mixed industrial effluents and landfill leachate with $64 \%$ of contribution in the pre-lockdown period decreased to $45 \%$ of contribution in the post-lockdown period. Vehicular pollution in the pre-lockdown period reduced from 13 to $5 \%$ in the post-lockdown period combined with the agricultural effluents.

3- The non-carcinogenic risk was reduced by $30 \%$ for all age groups. Although the carcinogenic risks decreased $47 \%$ during the lockdown period, the $C R$ values of As and $\mathrm{Cr}$ indicated cancer risk both pre-lockdown and post-lockdown periods.

4- The mean values of $S A R$ and EC increased 4 and 1.2 times in the post-lockdown period due to natural and anthropogenic sources such as an increase of municipal wastewater.

Overall, the lockdown period has had positive and negative impacts on the level of pollution and salinity/alkalinity, respectively.

Supplementary Information The online version contains supplementary material available at https://doi.org/10.1007/s11356-021-18286-5.

Author contribution Hamed Haghnazar: Conceptualization, Methodology, Formal analysis, Writing-Original Draft, Visualization.

Jeffrey A. Cunningham: Supervision, Conceptualization, Methodology, Writing-Review \& Editing.

Vinod Kumar: Conceptualization, Methodology, Writing-Review \& Editing.

Ehsan Aghayani: Resources, Investigation, Project administration. Mojtaba Mehraein: Resources, Investigation, Writing—Review \& Editing.

Data availability Data is available if requested.

\section{Declarations}

Ethics approval No animals were involved in this study.

Consent to participate No human participants were involved in this study.

Consent for publication No human participants were involved in this study.

Conflict of interest The authors declare no competing interests. 


\section{References}

Abdel-Satar AM, Ali MH, Goher ME (2017) Indices of water quality and metal pollution of Nile River. Egypt the Egyptian Journal of Aquatic Research 43(1):21-29

Aletta F, Oberman T, Mitchell A, Tong H, Kang J (2020) Assessing the changing urban sound environment during the COVID-19 lockdown period using short-term acoustic measurements. Noise Mapping 7(1):123-134

Alobaidy AHMJ, Al-Sameraiy MA, Kadhem AJ, Majeed AA (2010) Evaluation of treated municipal wastewater quality for irrigation. J Environ Prot 1(03):216

Arya, S., Subramani, T., Vennila, G., \& Karunanidhi, D. (2019). Health risks associated with fluoride intake from rural drinking water supply and inverse mass balance modeling to decipher hydrogeochemical processes in Vattamalaikarai River basin, South India. Environmental geochemistry and health, 1-12.

Ashayeri MS, Khaledian MR, Kavoosi-Kalashami M, Rezaei M (2020) Evaluation of energy balance and greenhouse gas emissions in rice cultivation in Guilan province, northern Iran. Paddy Water Environ, 18(1):261-272

Ayers RS, Westcot DW (1985) Water quality for agriculture, vol 29. Food and Agriculture Organization of the United Nations, Rome

Bashir, M. F., Benghoul, M., Numan, U., Shakoor, A., Komal, B., Bashir, M. A., ... \& Tan, D. (2020). Environmental pollution and COVID-19 outbreak: insights from Germany. Air Quality, Atmosphere \& Health, 1-10.

Berhe BA (2020) Evaluation of groundwater and surface water quality suitability for drinking and agricultural purposes in Kombolcha town area, eastern Amhara region. Ethiopia Applied Water Science 10(6):1-17

Bodrud-Doza M, Islam AT, Ahmed F, Das S, Saha N, Rahman MS (2016) Characterization of groundwater quality using water evaluation indices, multivariate statistics and geostatistics in central Bangladesh. Water Science 30(1):19-40

Braga, F., Scarpa, G. M., Brando, V. E., Manfè, G., \& Zaggia, L. (2020). COVID-19 lockdown measures reveal human impact on water transparency in the Venice Lagoon. Science of The Total Environment, 139612.

Broomandi P, Karaca F, Nikfal A, Jahanbakhshi A, Tamjidi M, Kim JR (2020) Impact of COVID-19 event on the air quality in Iran. Aerosol and Air Quality Research 20(8):1793-1804

Chakraborty, S., Mitra, A., Pramanick, P., Zaman, S., \& Mitra, A. (2020). Scanning the water quality of lower Gangetic delta during COVID-19 lockdown phase using Dissolved Oxygen (DO) as proxy. NUJS Journal of Regulatory Studies Special Issue.

Charkhabi AH, Sakizadeh M, Bayat R (2008) Land use effects on heavy metal pollution of river sediments in Guilan, southwest of the Caspian sea. Caspian Journal of Environmental Science 6(2):133-140

Chung SY, Venkatramanan S, Park N, Ramkumar T, Sujitha SB, Jonathan MP (2016) Evaluation of physico-chemical parameters in water and total heavy metals in sediments at Nakdong River Basin. Korea Environmental Earth Sciences 75(1):50

Custodio M, Cuadrado W, Peñaloza R, Montalvo R, Ochoa S, Quispe J (2020) Human risk from exposure to heavy metals and arsenic in water from rivers with mining influence in the Central Andes of Peru. Water 12(7):1946

Custodio, M., Peñaloza, R., Alvarado, J., Chanamé, F., \& Maldonado, E. (2021). Surface water quality in the Mantaro River Watershed assessed after the cessation of anthropogenic activities due to the COVID-19 pandemic. Polish Journal of Environmental Studies, 30(4).

Daneshpazhooh M, Mahmoudi H (2021) COVID-19: The experience from Iran. Clin Dermatol 39(1):23-32
Dantas, G., Siciliano, B., França, B. B., da Silva, C. M., \& Arbilla, G. (2020). The impact of COVID-19 partial lockdown on the air quality of the city of Rio de Janeiro, Brazil. Science of the Total Environment, 729, 139085.

Duodu GO, Goonetilleke A, Ayoko GA (2016) Comparison of pollution indices for the assessment of heavy metal in Brisbane River sediment. Environ Pollut 219:1077-1091

Edet, A. E., \& Offiong, O. E. (2002). Evaluation of water quality pollution indices for heavy metal contamination monitoring. A study case from Akpabuyo-Odukpani area, Lower Cross River Basin (southeastern Nigeria). GeoJournal, 57(4), 295-304.

Fakhradini SS, Moore F, Keshavarzi B, Lahijanzadeh A (2019) Polycyclic aromatic hydrocarbons (PAHs) in water and sediment of Hoor Al-Azim wetland, Iran: a focus on source apportionment, environmental risk assessment, and sediment-water partitioning. Environ Monit Assess 191(4):233

Fallahati A, Soleimani H, Alimohammadi M, Dehghanifard E, Askari M, Eslami F, Karami L (2020) Impacts of drought phenomenon on the chemical quality of groundwater resources in the central part of Iran-Application of GIS technique. Environ Monit Assess 192(1):64

FAO (1985) Water quality for agriculture. Food and Agriculture Organization, Rome

Garg V, Aggarwal SP, Chauhan P (2020) Changes in turbidity along Ganga River using Sentinel-2 satellite data during lockdown associated with COVID-19. Geomat Nat Haz Risk 11(1):1175-1195

Ghodrati A, Behzadi J, Dadashi MA, Amiri M (2012) Some of the causes of pollution in the Black River watershed (Zarjub basin). International Journal of Agriculture and Crop Sciences (IJACS) 4(7):350-353

Gibb HJ, Lees PS, Pinsky PF, Rooney BC (2000) Lung cancer among workers in chromium chemical production. Am J Ind Med 38(2): $115-126$

Giri S, Singh AK (2014) Assessment of surface water quality using heavy metal pollution index in Subarnarekha River, India. Water Qual Expo Health 5(4):173-182

Giri S, Singh AK (2015) Human health risk assessment via drinking water pathway due to metal contamination in the groundwater of Subarnarekha River Basin. India Environmental Monitoring and Assessment 187(3):63

Gu YG, Gao YP (2018) Bioaccessibilities and health implications of heavy metals in exposed-lawn soils from 28 urban parks in the megacity Guangzhou inferred from an in vitro physiologicallybased extraction test. Ecotoxicol Environ Saf 148:747-753

World Health Organization, (2011). Guidelines for drinking water quality, fourth ed. Geneva: WHO, 564p. ISBN: 978924 1548151.

Guilan Meteorological Organization. (2020). Bulletins of Guilan province weather. https://gilmet.ir/

Gyimah, R. A. A., Gyamfi, C., Anornu, G. K., Karikari, A. Y., \& Tsyawo, F. W. (2020). Multivariate statistical analysis of water quality of the Densu River, Ghana. International Journal of River Basin Management, 1-11.

Hasan, M. M., Ahmed, M. S., Adnan, R., \& Shafiquzzaman, M. (2020). Water quality indices to assess the spatiotemporal variations of Dhaleshwari river in central Bangladesh. Environmental and Sustainability Indicators, 8, 100068.

Hoseini M, Valizadeh A (2021) The effect of COVID-19 lockdown and the subsequent reopening on consumption in Iran. Rev Econ Household 19(2):373-397

Hung JJ, Yang CY, Lai IJ, Li YH (2020) Rainfall and human impacts on weathering rates and carbon-nutrient yields in the watershed of a small mountainous river (Kaoping) in Southwestern Taiwan. Sustainability 12(18):7689 
Ilyas, S., Srivastava, R. R., \& Kim, H. (2020). Disinfection technology and strategies for COVID-19 hospital and bio-medical waste management. Science of the Total Environment, 749, 141652.

Iran Department of Environment. (2005). Developing pollution discharge permits in the Zarjoub River basin, Tech Rep (in Persian).

Islam AT, Shen S, Bodrud-Doza MD, Rahman MS (2017) Assessing irrigation water quality in Faridpur district of Bangladesh using several indices and statistical approaches. Arab J Geosci 10(19):418

Islam MS, Hossain MB, Matin A, Sarker MSI (2018) Assessment of heavy metal pollution, distribution and source apportionment in the sediment from Feni River estuary, Bangladesh. Chemosphere 202:25-32

Jaskuła J, Sojka M, Fiedler M, Wróżyński R (2021) Analysis of spatial variability of river bottom sediment pollution with heavy metals and assessment of potential ecological hazard for the Warta River. Poland Minerals 11(3):327

Kargar, S., Pourmehdi, M., \& Paydar, M. M. (2020). Reverse logistics network design for medical waste management in the epidemic outbreak of the novel coronavirus (COVID-19). Science of The Total Environment, 746, 141183.

Karimi, A., Naghizadeh, A., Biglari, H., Peirovi, R., Ghasemi, A., \& Zarei, A. (2020). Assessment of human health risks and pollution index for heavy metals in farmlands irrigated by effluents of stabilization ponds. Environmental Science and Pollution Research, 1-11.

Karunanidhi, D., Aravinthasamy, P., Subramani, T., \& Setia, R. (2021). Effects of COVID-19 pandemic lockdown on microbial and metals contaminations in a part of Thirumanimuthar River, South India: a comparative health hazard perspective. Journal of Hazardous Materials, 125909

Kataki, S., Chatterjee, S., Vairale, M. G., Sharma, S., \& Dwivedi, S. K. (2020). Concerns and strategies for wastewater treatment during COVID-19 pandemic to stop plausible transmission. Resources, Conservation and Recycling, 105156.

Khan MYA, Gani KM, Chakrapani GJ (2017) Spatial and temporal variations of physicochemical and heavy metal pollution in Ramganga River-a tributary of River Ganges. India Environmental Earth Sciences 76(5):231

Khan, R., Saxena, A., \& Shukla, S. (2021). Assessment of the impact of COVID-19 lockdown on the heavy metal pollution in the River Gomti, Lucknow city, Uttar Pradesh, India. Environmental Quality Management.

Kumar V, Sharma A, Kumar R, Bhardwaj R, Kumar Thukral A, Rodrigo-Comino J (2020) Assessment of heavy-metal pollution in three different Indian water bodies by combination of multivariate analysis and water pollution indices. Hum Ecol Risk Assess Int J 26(1):1-16

Kumar, V., Parihar, R. D., Sharma, A., Bakshi, P., Sidhu, G. P. S., Bali, A. S., \& Rodrigo-Comino, J. (2019). Global evaluation of heavy metal content in surface water bodies: a meta-analysis using heavy metal pollution indices and multivariate statistical analyses. Chemosphere, 236, 124364.

Kuo HW, Shu SL, Wu CC, Lai JS (1999) Characteristics of medical waste in Taiwan. Water Air Soil Pollut 114(3-4):413-421

Liang B, Han G, Zeng J, Qu R, Liu M, Liu J (2020) Spatial variation and source of dissolved heavy metals in the Lancangiiang River, Southwest China. Int J Environ Res Public Health 17(3):732

Linos A, Petralias A, Christophi CA, Christoforidou E, Kouroutou P, Stoltidis M, Karagas MR (2011) Oral ingestion of hexavalent chromium through drinking water and cancer mortality in an industrial area of Greece-an ecological study. Environ Health 10(1):50

Mandal, I., \& Pal, S. (2020). COVID-19 pandemic persuaded lockdown effects on environment over stone quarrying and crushing areas. Science of The Total Environment, 732, 139281.
Marnie, C., \& Peters, M. D. (2020). ANMF Evidence Brief Covid-19: cleaning and disinfection of hospital surfaces and equipment. Australian Nursing and Midwifery Federation.

Mehraein, M., Torabi, M., Sangsefidi, Y., \& MacVicar, B. (2020). Numerical simulation of free flow through side orifice in a circular open-channel using response surface method. Flow Measurement and Instrumentation, 76, 101825.

Monavari SM, Hoasami P, Tajziehchi S, Khorramichokami N, Area AS (2012) Study of solid waste landfill suitability using regional screening method and AHP in Rasht City. Int J Engine Phys Sci 6(1):2-27

Morrison G, Fatoki OS, Persson L, Ekberg A (2001) Assessment of the impact of point source pollution from the Keiskammahoek Sewage Treatment Plant on the Keiskamma River-pH, electrical conductivity, oxygen-demanding substance (COD) and nutrients. Water Sa 27(4):475-480

Mostafa, M. K., Gamal, G., \& Wafiq, A. (2021). The impact of COVID 19 on air pollution levels and other environmental indicatorsa case study of Egypt. Journal of environmental management, 277, 111496.

Muhammad, S., Long, X., \& Salman, M. (2020). COVID-19 pandemic and environmental pollution: a blessing in disguise?. Science of The Total Environment, 138820.

Nabi, G., Wang, Y., Hao, Y., Khan, S., Wu, Y., \& Li, D. (2020). Massive use of disinfectants against COVID-19 poses potential risks to urban wildlife. Environmental Research, 188, 109916.

Nasrabadi T, Maedeh PA, Sirdari ZZ, Bidabadi NS, Solgi S, Tajik M (2015) Analyzing the quantitative risk and hazard of different waterborne arsenic exposures: case study of Haraz River. Iran Environmental Earth Sciences 74(1):521-532

Nematollahi MJ, Clark MJR, Ebrahimi P, Ebrahimi M (2018) Preliminary assessment of groundwater hydrogeochemistry within Gilan, a northern province of Iran. Environ Monit Assess 190(4):1-23

Nguyen, B. T., Do, D. D., Nguyen, T. X., Nguyen, V. N., Nguyen, D. T. P., Nguyen, M. H., ... \& Bach, Q. V. (2020). Seasonal, spatial variation, and pollution sources of heavy metals in the sediment of the Saigon River, Vietnam. Environmental Pollution, 256, 113412.

Nickmilder M, Carbonnelle S, Bernard A (2007) House cleaning with chlorine bleach and the risks of allergic and respiratory diseases in children. Pediatr Allergy Immunol 18(1):27-35

Olıas M, Nieto JM, Sarmiento AM, Cerón JC, Cánovas CR (2004) Seasonal water quality variations in a river affected by acid mine drainage: the Odiel River (South West Spain). Sci Total Environ 333(1-3):267-281

Pan H, Lu X, Lei K (2017) A comprehensive analysis of heavy metals in urban road dust of Xi'an, China: contamination, source apportionment and spatial distribution. Sci Total Environ 609:1361-1369

Patel, P. P., Mondal, S., \& Ghosh, K. G. (2020). Some respite for India's dirtiest river? Examining the Yamuna's water quality at Delhi during the COVID-19 lockdown period. Science of the Total Environment, 744, 140851.

Pereira SSP, Oliveira HMD, Turrini RNT, Lacerda RA (2015) Disinfection with sodium hypochlorite in hospital environmental surfaces in the reduction of contamination and infection prevention: a systematic review. Rev Esc Enferm USP 49(4):0681-0688

Pokrovski GS, Kara S, Roux J (2002) Stability and solubility of arsenopyrite, FeAsS, in crustal fluids. Geochim Cosmochim Acta 66(13):2361-2378

Puczko K, Jekatierynczuk-Rudczyk E (2020) Extreme hydro-meteorological events influence to water quality of small rivers in urban area: a case study in Northeast Poland. Sci Rep 10(1):1-14

Qu L, Huang H, Xia F, Liu Y, Dahlgren RA, Zhang M, Mei K (2018) Risk analysis of heavy metal concentration in surface waters 
across the rural-urban interface of the Wen-Rui Tang River, China. Environ Pollut 237:639-649

Rao GS, Nageswararao G (2010) Study of groundwater quality in Greater Visakhapatnam City, Andhra Pradesh (India). J Environ Sci Eng 52(2):137-146

Raoofi A, Takian A, Sari AA, Olyaeemanesh A, Haghighi H, Aarabi M (2020) COVID-19 pandemic and comparative health policy learning in Iran. Arch Iran Med 23(4):220-234

Rohila, S.K., 2020. COVID-19 outbreak: more hand washing can increase India's water woes. Available at: https://www.downt oearth.org.in/blog/water/covid-19-outbreakmore-hand-washi ng-can-increase-india-s-water-woes-69900

Saffarzadeh A, Arumugam N, Shimaoka T (2016) Aluminum and aluminum alloys in municipal solid waste incineration (MSWI) bottom ash: a potential source for the production of hydrogen gas. Int J Hydrogen Energy 41(2):820-831

Saha N, Rahman MS, Ahmed MB, Zhou JL, Ngo HH, Guo W (2017) Industrial metal pollution in water and probabilistic assessment of human health risk. J Environ Manage 185:70-78

Sahoo, S., \& Khaoash, S. (2020). Impact assessment of coal mining on groundwater chemistry and its quality from Brajrajnagar coal mining area using indexing models. Journal of Geochemical Exploration, 106559.

Sakai N, Mohamad ZF, Nasaruddin A, Abd Kadir SN, Salleh MSAM, Sulaiman AH (2018) Eco-Heart Index as a tool for community-based water quality monitoring and assessment. Ecol Ind 91:38-46

Saleem M, Iqbal J, Shah MH (2019) Seasonal variations, risk assessment and multivariate analysis of trace metals in the freshwater reservoirs of Pakistan. Chemosphere 216:715-724

Sangsefidi Y, Mehraein M, Ghodsian M, Motalebizadeh MR (2017) Evaluation and analysis of flow over arced weirs using traditional and response surface methodologies. J Hydraul Eng 143(11):04017048

Setia, R., Dhaliwal, S. S., Kumar, V., Singh, R., Kukal, S. S., \& Pateriya, B. (2020). Impact assessment of metal contamination in surface water of Sutlej River (India) on human health risks. Environmental Pollution, 265, 114907.

Shariatmadari N, Lasaki BA, Eshghinezhad H, Alidoust P (2018) Effects of landfill leachate on mechanical behaviour of adjacent soil: a case study of saravan landfill, rasht, iran. International Journal of Civil Engineering 16(10):1503-1513

Sheijany MSP, Shariati F, Mahabadi NY, Karimzadegan H (2020) Evaluation of heavy metal contamination and ecological risk of soil adjacent to Saravan municipal solid waste disposal site, Rasht. Iran Environmental Monitoring and Assessment 192(12):1-19

Shukla T, Sen IS, Boral S, Sharma S (2021) A time-series record during COVID-19 lockdown shows the high resilience of dissolved heavy metals in the Ganga River. Environ Sci Technol Lett 8(4):301-306

Simsek C, Gunduz O (2007) IWQ index: a GIS-integrated technique to assess irrigation water quality. Environ Monit Assess 128(1-3):277-300

Smith AH, Hopenhayn-Rich C, Bates MN, Goeden HM, Hertz-Picciotto I, Duggan HM, Smith MT (1992) Cancer risks from arsenic in drinking water. Environ Health Perspect 97:259-267

Sojka M, Jaskuła J, Siepak M (2019) Heavy metals in bottom sediments of reservoirs in the lowland area of western Poland: concentrations, distribution, sources and ecological risk. Water 11(1):56

Somma, R., Ebrahimi, P., Troise, C., De Natale, G., Guarino, A., Cicchella, D., \& Albanese, S. (2021). The first application of compositional data analysis (CoDA) in a multivariate perspective for detection of pollution source in sea sediments: the Pozzuoli Bay (Italy) case study. Chemosphere, 274, 129955.

Tchounwou P.B., Yedjou C.G., Patlolla A.K., Sutton D.J. (2012) Heavy metal toxicity and the environment. In: Luch A. (eds) Molecular,
Clinical and Environmental Toxicology. Experientia Supplementum, vol 101. Springer, Basel.

Tokatl, C., \& Varol, M. (2021). Impact of the COVID-19 lockdown period on surface water quality in the Meriç-Ergene River Basin, Northwest Turkey. Environmental Research, 197, 111051.

Iran Water Resource Management Company. (2013). Trading pollutant discharge permits for river water quality management, Tech Rep (in Persian).

USEPA, (2004). Risk Assessment Guidance for Superfund Volume 1. Human Health Evaluation Manual (Part E, Supplemental Guidance for Dermal Risk Assessment). EPA/540/R/99/005 Office of Superfund Remediation and Technology Innovation; U.S. Environmental Protection Agency, Washington, DC.

USEPA, (2006). National Recommended Water Quality Criteria. United States Environmental Protection Agency. Office of Water, Office of Science and Technology

Ustaoğlu, F., \& Islam, M. S. (2020). Potential toxic elements in sediment of some rivers at Giresun, Northeast Turkey: a preliminary assessment for ecotoxicological status and health risk. Ecological Indicators, 113, 106237.

Vanapalli, K. R., Sharma, H. B., Ranjan, V. P., Samal, B., Bhattacharya, J., Dubey, B. K., \& Goel, S. (2020). Challenges and strategies for effective plastic waste management during and post COVID19 pandemic. Science of The Total Environment, 750, 141514.

Vu CT, Lin C, Shern CC, Yeh G, Tran HT (2017) Contamination, ecological risk and source apportionment of heavy metals in sediments and water of a contaminated river in Taiwan. Ecol Ind 82:32-42

Wang L, Wang Y, Xu C, An Z, Wang S (2011) Analysis and evaluation of the source of heavy metals in water of the River Changjiang. Environ Monit Assess 173(1-4):301-313

Wang Y, Wang P, Bai Y, Tian Z, Li J, Shao X, Li BL (2013) Assessment of surface water quality via multivariate statistical techniques: a case study of the Songhua River Harbin region. China Journal of Hydro-Environment Research 7(1):30-40

Wang J, Liu G, Liu H, Lam PK (2017) Multivariate statistical evaluation of dissolved trace elements and a water quality assessment in the middle reaches of Huaihe River, Anhui, China. Sci Total Environ 583:421-431

Wang, Q., \& Su, M. (2020). A preliminary assessment of the impact of COVID-19 on environment-a case study of China. Science of the Total Environment, 138915.

Wang, J., Lei, Y., Chen, Y., Wu, Y., Ge, X., Shen, F., ... \& Chen, M. (2021). Comparison of air pollutants and their health effects in two developed regions in China during the COVID-19 pandemic. Journal of environmental management, 287, 112296.

WHO (2020a) Rational use of personal protective equipment (PPE) for coronavirus disease (COVID-19): interim guidance, March 19,2020

WHO (2020b) Director-General's opening remarks at the media briefing on COVID-19 - 11 March 2020

Wu B, Zhao DY, Jia HY, Zhang Y, Zhang XX, Cheng SP (2009) Preliminary risk assessment of trace metal pollution in surface water from Yangtze River in Nanjing Section, China. Bull Environ Contam Toxicol 82(4):405-409

Xiao J, Wang L, Deng L, Jin Z (2019) Characteristics, sources, water quality and health risk assessment of trace elements in river water and well water in the Chinese Loess Plateau. Sci Total Environ 650:2004-2012

Xiao, J., Wang, L., Chai, N., Liu, T., Jin, Z., \& Rinklebe, J. (2021). Groundwater hydrochemistry, source identification and pollution assessment in intensive industrial areas, eastern Chinese loess plateau. Environmental Pollution, 278, 116930.

Xiong B, Li R, Johnson D, Luo Y, Xi Y, Ren D, Huang Y (2021) Spatial distribution, risk assessment, and source identification of heavy metals in water from the Xiangxi River, Three Gorges 
Reservoir Region. China Environmental Geochemistry and Health 43(2):915-930

Yadav, A. K., Khan, P., \& Sharma, S. K. (2010). Water quality index assessment of groundwater in Todaraisingh Tehsil of Rajasthan State, India- a greener approach. E-journal of Chemistry, 7.

Yang X, Duan J, Wang L, Li W, Guan J, Beecham S, Mulcahy D (2015) Heavy metal pollution and health risk assessment in the Wei River in China. Environ Monit Assess 187(3):111

Yegemova S, Kumar R, Abuduwaili J, Ma L, Samat A, Issanova G, Rodrigo-Comino J (2018) Identifying the key information and land management plans for water conservation under dry weather conditions in the Border areas of the Syr Darya River in Kazakhstan. Water 10(12): 1754

Yunus, A. P., Masago, Y., \& Hijioka, Y. (2020). COVID-19 and surface water quality: improved lake water quality during the lockdown. Science of The Total Environment, 139012.

Yusof N, Haraguchi A, Hassan MA, Othman MR, Wakisaka M, Shirai Y (2009) Measuring organic carbon, nutrients and heavy metals in rivers receiving leachate from controlled and uncontrolled municipal solid waste (MSW) landfills. Waste Manage 29(10):2666-2680

Zambrano-Monserrate, M. A., Ruano, M. A., \& Sanchez-Alcalde, L. (2020). Indirect effects of COVID-19 on the environment. Science of the Total Environment, 138813.
Zeng, J., Han, G., Wu, Q., \& Tang, Y. (2019). Geochemical characteristics of dissolved heavy metals in Zhujiang River, Southwest China: spatial-temporal distribution, source, export flux estimation, and a water quality assessment. PeerJ, 7, e6578.

Zhang Z, Lu Y, Li H, Tu Y, Liu B, Yang Z (2018) Assessment of heavy metal contamination, distribution and source identification in the sediments from the Zijiang River, China. Sci Total Environ 645:235-243

Zhang, X., Tang, M., Guo, F., Wei, F., Yu, Z., Gao, K., ... \& Chen, K. (2021). Associations between air pollution and COVID-19 epidemic during quarantine period in China. Environmental Pollution, 268, 115897.

Zolfagharipoor MA, Ahmadi A (2016) A decision-making framework for river water quality management under uncertainty: application of social choice rules. J Environ Manage 183:152-163

Publisher's Note Springer Nature remains neutral with regard to jurisdictional claims in published maps and institutional affiliations. 